\title{
Predzgodovina praslovanskega naglasnega sistema v luči moskovske naglasoslovne šole
}

\author{
Matej Šekli
}

Cobiss: 1.01

Профессору В. А. Дьбо к восьмидесятилетнему юбилею

V prispevku je podan pregled teorije moskovske naglasoslovne šole o predzgodovini praslovanskega naglasnega sistema. Gre za enega od poskusov pojasniti oblikovanje praslovanskega naglasnega sistema iz praindoevropskega preko vmesnega prabaltoslovanskega. Moskovska teorija ima za osnovo oblikoslovni pristop, središče katerega je naglasni tip. V svoj teoretični sistem vgrajuje nekatere prvine klasičnega naglasoslovja, nadgrajuje Stangovo teorijo, prabaltoslovanski naglasni sistem prikaže na tvorbeno-pretvorbeni način.

Ključne besede: naglasoslovje, baltoslovanščina, moskovska naglasoslovna šola, oblikonaglas, naglasni tip

Prehistory of the Proto-Slavic accentual system according to the Moscow Accentological School

This article reviews the Moscow Accentological School theory of the prehistory of the Proto-Slavic accentual system. The Moscow theory is one of several attempts to explain the formation of the Proto-Slavic accentual system from its Proto-Indo-European source through the intermediate Balto-Slavic system. The Moscow theory is based on the morphological approach, the central focus of which is accentual paradigm. This theoretical system is characterized by several elements of classical accentology, builds on Stang's theory, and presents the Proto-Balto-Slavic system in a transformational-generative manner.

Key words: accentology, Balto-Slavic, Moscow Accentological School, morphoaccent, accent paradigm

\section{$0 \quad$ Uvod}

V primerjalnem naglasoslovju slovanskih jezikov velja za bolj ali manj nesporno rekonstrukcija praslovanskega naglasnega sistema, tj. posameznih oblikotvornih in besedotvornih naglasnih tipov ter vanje spadajočih leksemov. Razhajanja se pojavljajo pri interpretaciji nastanka rekonstruiranega praslovanskega naglasnega sistema v odnosu do njegovega praindoevropskega izhodišča. Tako obstaja več v nekaterih točkah med seboj izključujočih se modelov geneze praslovanskega naglasnega sistema, eden od katerih je tudi moskovski model avtorjev V. A. Dyboja in 
V. M. lliča-Svityča, ${ }^{1}$ ki predstavlja osrednji model v baltoslovanskem naglasoslovju druge polovice 20. in začetka 21. stoletja. Podobno kot ostali sodobni naglasoslovni modeli ima tudi moskovski za osnovo standardni »oblikoslovni« metodološki pristop (rus. морфологическая концепция в акцентологии), katerega središče je naglasni tip. V svoj teoretični sistem vgrajuje nekatera spoznanja »glasoslovnega« pristopa (rus. фонетическая концепция в акцентологии) »klasičnega« predstangovskega naglasoslovja (Bezzenberger, Fortunatov, de Saussure, Leskien, Hanssen, Hirt, Šahmatov, Meillet, Vasiljev in Dolobko, Ivšić, Bulahovski), katerega težišče je bilo odkrivanje naglasnih sprememb in postavljanje naglasnih zakonov, izhaja iz dela norveškega jezikoslovca Ch. S. Stanga Slavonic accentuation (1957), prabaltoslovanski naglasni sistem v okviru teorije naglasne valence morfemov pa tipološko prikaže na tvorbeno-pretvorbeni način. Spoznanja moskovske naglasoslovne šole so v znanstveni javnosti prisotna od prvih naglasoslovnih objav V. A. Dyboja, osrednje osebnosti moskovske naglasoslovne šole, leta $1958 .^{2}$

Središče »oblikoslovnega« metodološkega pristopa v naglasoslovju je spoznanje o vpetosti naglasnih prvin (naglasno mesto, zložniška kolikost, tonem) v naglasni tip ali akcentsko paradigmo. Naglasni tip je vzorec razporeditve naglasnega mesta ter različnih zložniških kolikosti in tonemov znotraj pregibalnih vzorcev ali fleksijskih paradigem pregibnih besednih vrst (tj. sklanjatvenih, spregatvenih in vzorcev pregibanja po spolu). Tako razumljen naglasni tip je torej tesno povezan s pojavljanjem naglasa v oblikovju, znotraj katerega je smotrno posebej razlikovati naglas $\mathrm{v}$ oblikotvorju od naglasa $\mathrm{v}$ besedotvorju ter posledično oblikotvorne in besedotvorne naglasne tipe.

\section{$1 \quad$ Praslovanski naglasni sistem}

Praslovansko sinhrono gledano je netvorjene in tvorjene pregibne besedne vrste mogoče razvrstiti v posamezne praslovanske oblikotvorne in besedotvorne naglasne

1 Med odmevnimi modeli geneze praslovanskega naglasnega sistema so poleg Dybojevega in Illič-Svityčevega vsaj še Kortlandtov (Frederik Kortland, Slavic accentuation: a study in relative chronology, Lisse 1975), Rasmussenov (Jens E. Rasmussen, Die Vorgeschichte der baltoslavischen Akzentuierung: Beiträge zu einer vereinfachten Lösung, Indogermanisch, Slawisch und Baltisch: Materialien des vom 21.-22. September 1989 in Jena in Zusammenarbeit mit der Indogermanischen Gesellschaft durchgeführten Kolloquiums, ur. B. Barschel - M. Kozianka - K. Weber, München, 1992 (Slavistische Beiträge 285), 173-200) in Klingenschmittov (Gert Klingenschmitt, Die Bedeutung des Slovenischen für die Rekonstruktion der urslavischen Akzentverhältnisse, izroček, predavanje v Lingvističnem krožku Filozofske fakultete, Ljubljana, 22. 10. 1990).

2 Illič-Svityč 1963; Dybo 1981, 2000; Zaliznjak 1985; Dybo - Zamjatina - Nikolajev 1990, 1993. - Po letu 1990 (po Dybo - Zamjatina - Nikolajev 1990) je v pogledih moskovske naglasoslovne šole na genezo praslovanskega naglasnega sistema prišlo do spremembe pri poimenovanju praslovanskega naglasnega pomika po Dybojevem zakonu, na kar je v pričujočem delu opozorjeno, pri čemer pa je predstavljeno stanje pojmovanja do leta 1990 (prim. 4.2). 
tipe, pri čemer je prehajanje iz naglasnega tipa $\mathrm{v}$ naglasni tip $\mathrm{v}$ besedotvorju posledica praslovanske metatonije.

\subsection{Praslovanski oblikotvorni naglasni tipi}

Praslovanski oblikotvorni naglasni tipi so značilni za netvorjene in z neproduktivnimi praslovanskimi priponskimi obrazili izpeljane (za)imenske besedne vrste (samostalnik, pridevnik, zaimek) ter za sedanjik glagola. Po klasični Stangovi teoriji (Stang 1957: 56-167) je praslovanščina poznala tri tovrstne naglasne tipe (a, b, c), moskovska naglasoslovna šola pa je za nekatere sklanjatvene vzorce odkrila še četrtega (d).

\subsubsection{Praslovanski oblikotvorni naglasni tip a}

Za praslovanski oblikotvorni naglasni tip a je bilo značilno nepremično naglasno mesto na korenu in staroakutski tonem v vseh oblikah: a) samostalniki: sln. vớlna

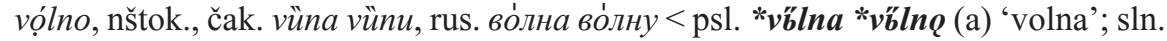
lípa lípo, nštok., čak. lïpa lïpu, rus. лuna лúny, češ. lípa lípu < psl. *lípa *lípo (a) 'lipa'; sln. gríva grívo, nštok., čak. grïva grïvu, rus. грuвва грúвy, češ. hřiva hřivu < psl. *grîva *grîve (a) 'griva'; sln. brät bráta, nštok., čak. brät bräta, rus. бpám бpàma, češ. (bratr bratra) < psl. *brätrz *brätra (a) 'brat'; sln. dïm díma, nštok.

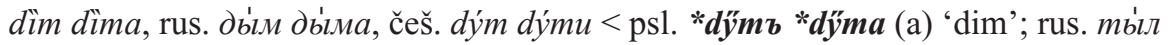
ть'ла, с̌еš. týl týlu< psl. *tỷlb *tÿla (a) 'tilnik'; sln. šílo, nštok., čak. šìlo, rus. шиंло, češ. šídlo < psl. *šídlo (a) ‘šilo'; sln. sito, nštok., čak. sïto, rus. cúmo, češ. síto < psl. *sïto (a) 'sito'; ${ }^{3}$ b) pridevniki: nar. sln. pöln pọ́lna pọlno, nštok., čak. pün püna püno

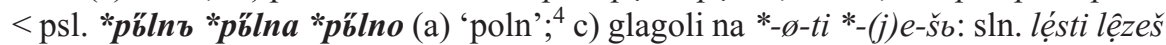
lệzete, nštok. ljēsti ljëzēš ljëzête, lësti lëzēš lëzète, čak. lïst lïzeš lìzete, rus. лéзmь ле́зешь ле́зете, brus. ле́зиі ле́зеш ле́зеце, ukr. лісти лізеш лізете, с̌еš. lézt lezеš lezete < psl. *lếsti *lĕ̃zešb *lë̌zete (a); sln. šiti šîješ šîjete, nštok. šìti šìjēš šìjēte, čak.

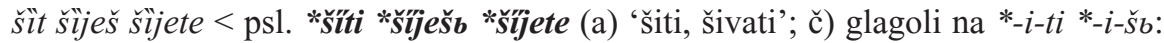
sln. mệriš mệrite, nštok. mjërīš mjërīte, mërī̌s mërīte, čak. mïriš mïrite, rus. мépumь мépume, češ. méř́š měřite < psl. *mêّrišs *mễrite (a).

\subsubsection{Praslovanski oblikotvorni naglasni tip b}

Za praslovanski oblikotvorni naglasni tip b je bilo značilno nepremično naglasno mesto na prvem/edinem zlogu končnice v sklanjatvi oziroma na prvem zlogu desno od korena v spregatvi, na katerem se pojavlja tonem tipa praslovanskega novega akuta (na dolžini ali na kračini), pri čemer prihaja do naglasnega umika s praslovanskega nestaroakutiranega zložnika na prednaglasni zlog ter do nastanka pozno-

3 Različica $\mathrm{z}$ drugačnim vokalizmom je ohranjena $\mathrm{v}$ stčeš. sieto $<$ psl. * sě̃to 'sito' (Metka Furlan v Bezlaj 1995: 239).

4 Pri navajanju primerjalnega gradiva iz slovanskih jezikov imajo prednost tiste knjižne različice in narečne tonemske oblike, ki izkazujejo starejše naglasno stanje (sln. nóga nogộ, žîv žíva živộ in ne nóga nógo, žîv žíva žívo; nar. sln. pöln pọ́lna pọ́lno in ne knj. sln. pộln pọ́lna pọ́lno). Knjižnoslovenske tonemske oblike so navajane po SSKJ in SP 2001, arhaične narečnoslovenske pa predstavljajo glasovno poknjižene oblike nadiškega narečja (Šekli 2006). Oblike, ki so posledica analognih izravnav, so navedene v oklepaju. 
praslovanskega novega akuta (na dolžini ali kračini): a) samostalniki: sln. svẹ́ča svẹćco, nštok. svijéća svijéću, svéća svéću, čak. svićâ svićü, rus. свечà свечỳ < psl. *svétá *světí (b); nar. sln. ženä ženö, nštok. žèna žènu, čak. ženä ženü, rus. женá жену̀ < psl. *ženà *ženò (b); sln. bọ́lha bọ́lho, nštok. bùha bùho, bùva bùvo, rus.

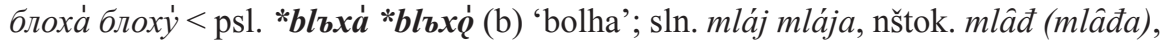
stčeš. mláz< psl. *móld́b *mold́á (b); knj. sln. pöd póda, nar. sln. pöd podä, nštok. pôd pòda < psl. *pòdț *podà (b) 'pod, tla'; star. knj. sln. žrệlo, češ. zř́idlo, nar. rus. жерело́ 'odprtina, ustje, jama' < psl. *žerdlo (b) 'žrelo'; star. knj. sln. načélo, počẹlo, ${ }^{5}$ nštok. načélo, počélo, vsl. csl. naчanẃ < psl. *-čędló (b); nar. sln. perö, čak. perö, rus. nepó < psl. “peró (b) 'pero'; b) pridevniki: nar. sln. óstər osträ oströ, nštok. öštar (öštra öštro), čak. öštar ošträ oštrö < psl. *òstrí *ostrá *ostró (b) 'oster'; c) glagoli na *-ø-ti *-(j)e-šb: sln. móči móreš mọ́rete, nštok. mòci möžēšs möžēte, rus. мо่чь мо่жешь мо́жете, с̌eš. moci můžeš můžete < psl. *moti *mòžešb *možete < *moti *možèšs *možète (b); sln. začéti začnëšs, nštok. zàčêti zäčnēšs, rus. зача́mь зачнёшь < psl. *začęti *začbnéšb (b); č) glagoli na *-i-ti $*_{-i-s ̌ b}$ : sln. blọdiš blọ́dite, nštok. blúdīš blúdīte, rus. блỳdишь блýduте, češ. bloudiśs bloudite < psl. *blódišb *blódite < *blqdišb *blqdite $\left(\mathrm{b}_{1}\right)$; sln. nọ́siš nọ́site, nštok. nösī̌ nösīte, čak. nösiš nösite, rus. но́сишь но̀сuте < psl. *nòsišs *nòsite < *nosišb *nosite $\left(\mathrm{b}_{1}\right)$.

\subsubsection{Praslovanski oblikotvorni naglasni tip c}

Osnovne oblike, s pomočjo katerih je mogoče določiti praslovanski naglasni tip c, so: a) samostalniki: sln. gláva glavộ, nštok. gláva glâvu, čak. glāvä glâvu, rus. голова голлову, с̌еš. (hlava) hlavu < psl. *golvá *gôlvQ (c) 'glava'; rus. цена́ цеंну < psl. *cěná *cènng (c) 'cena'; nar. sln. zíma zimộ, nštok. zíma zîmu, čak. zìmä zîmu, rus. зимá зймy, češ. (zima) zimu < psl. *zimà *zîmQ (c) 'zima'; knj. sln. nóga nogộ, nar. sln. nogä nogộ, nštok. nòga nögu, čak. nogä nögu, rus. ногá но́zy < psl. *nogà *nögQ (c) 'noga'; sln. smrâd smradû, nštok., čak. smrâd smrâda, nar. rus. смо̀род смо̀рода, с̌еš. smrad smradu < psl. *smôrdъ *smôrda (c) 'smrad'; nar. sln. mệh mehâ, nštok. mijêh mijêha, mêh mêha, čak. mîh mîha, rus. мéx мèxa, češ. měch měc$h u<$ psl. *mềx $\boldsymbol{b}$ *mềxa $(\mathrm{c})$ 'meh, vreča'; sln. mesộ, nštok., čak. mêso, rus. мя่co, češ. maso < psl. *mẹso (c) 'meso'; b) pridevniki: sln. žîv živa živộ, nštok. žîv žíva (žívo),

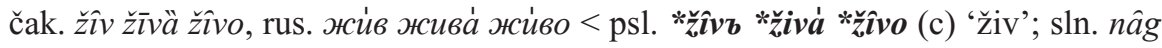
nága nagộ, nštok. nâg nága (nágo), čak. nâg nāgâ nâgo, rus. нáz нагá нázo < psl. *nâgb *nagà *nâgo (c) 'nag'; sln. sûh súha suhộ, nštok. sûh súha (súho), sûv súva (súvo), čak. sûh sūhä sûho, rus. cỳx cyxá cỳxo < psl. *sûxъ *suxà *sûxo (c) 'suh'; sln. mlâd mláda mladộ, nštok. mlâd mláda (mládo), čak. mlâd mlādä mlâdo, rus. мо́лод молода́ моллодо < psl. *môldъ *moldá *môldo (c); knj. sln. bộs bósa bosộ, nar. sln. bộs bosä bosộ, nštok. bôs bòsa (bòso), čak. bôs bosä böso, rus. бóc бocà бóco < psl. *bösı *bosáa *böso (c) 'bos'; c) glagoli na *-ø-ti *-(j)e-šb: star. knj. sln. nésti néseš neséte, nar. sln. nestì nesēš nesetë, nštok. nèsti nèsēšs (nèsēte), rus. несmù

5 Pričakovani odraz praslovanskega prednaglasnega dolgega samoglasnika je zabeležen v starejšem knjižnem jeziku (Pleteršnik: žrẹllo, načélo, počélọ), v sodobni knjižni slovenščini se pojavlja nepričakovana široka samoglasniška kakovost (SSJK, SP 2001: žrélo, načélo, počélo). 
несёшь (несёте), brus. (не́сиі) нясе́ш нясайе́, ukr. нестиं несе́ш несете́ < psl. *nesti *nesèšb̆ *neseté (c); sln. trẹsti trẹseš (trẹsete), nštok. trésti trésēš (trésēte), rus. трястиं трясёшь (трясёте), brus. (трэ́сиі) трасе́ш трасаце́, ukr. трястиं трясѐu трясете́ < psl. *tręsti *tręsèšb̆ *tręseté(c); č) glagoli na *-i-ti *-i-šb: sln. moríš morite, nštok. mòrīš (mòrīte), čak. morĩ̌s morītē, rus. морümb (морúme) (tip brus. крычьыш крычыцеं, ukr. кричиंш кричите́) < psl. *moríšb̆ *morité (c).

Za praslovanski oblikotvorni naglasni tip c je bilo značilno polarizirano premično naglasno mesto, kar pomeni, da se je le-to lahko nahajalo ali na prvem ali na zadnjem zlogu fonološke besede. To je zakon Vasiljeva in Dolobka (Vasiljev 1905; Dolobko 1927). ${ }^{6}$ Glede na pojavljanje naglasnega mesta v pregibalnem vzorcu je mogoče glede na fonološki status ločiti dvoje vrst oblik: fonološko naglašene in fonološko nenaglašene.

Fonološko naglašene oblike imajo lasten naglas, ki se v različnih skladenjskih zgradbah, v katerih se naglašena oblika pojavlja, ne spreminja, pri čemer je glede na vrsto naglasa mogoče ločiti tri vrste oblik: a) oblike z naglasom na zadnjem zlogu, tj. na edinem/zadnjem zlogu končnice: Isg sln. nogó, glavọ́ < *nogó, *glavố < psl. *nogojó, *golvojẹ; b) oblike s staroakutskim naglasom na predzanjem zlogu: sln. Dpl nogäm, Lpl nogäh, Ipl nogâmi, čak. Dpl nogän, Lpl nogäh, Ipl nogämi, slavonsko stštok. Dpl nogäm, Lpl nogäh, Ipl nogämī, rus. Dpl ногáм, Lpl ногáx, Ipl ногáми < psl. Dpl *nogämъ, Lpl *nogäxz, Ipl *nogámi; c) oblike z novoakutskim naglasom na predzadnjem zlogu in polglasnikom $\mathrm{v}$ zadnjem zlogu po poznopraslovanskem umiku naglasa s praslovanskega polglasnika $\mathrm{v}$ šibki poziciji

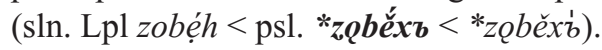

Fonološko nenaglašene oblike (oblike ne z naglasom na zadnjem ali pred-

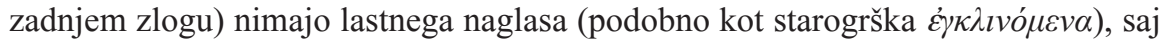
se naglas spreminja glede na besedno zvezo, v kateri se nenaglašena oblika pojavlja: a) na prvem zlogu fonološke besede, tj. na prvem zlogu osnove ali na (prvi) predslonki, se naglasno mesto, in sicer praslovanski stari cirkumfleks, pojavlja ob prisotnosti same polnopomenske besede ali ob prisotnosti polnopomenske zveze in

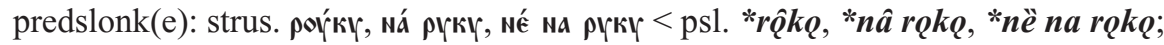

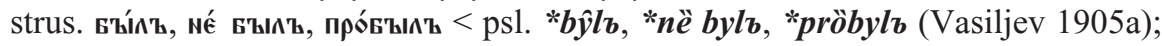
sln. nogộ, na nọgo, glavộ, na glâvo, čak., nštok. nögu, nä nogu, glâvu, nä glāvu, rus. но́гу : на́ ногу, го́лову, на́ голову < psl. *nögQ, *nâ nogQ, *gôlvQ, *nâ golvQ; sln. dân, dnệ, na dân< psl. *db̀nb, *dל̀ne, *nâ dbnb; b) na zadnjem zlogu fonološke besede, tj. na (enozložni) zaslonki, se naglas pojavlja ob prisotnosti polnopomenske besede (predslonk(e)) in zaslonke: rus. взялся, начался́, родился < psl. *vъzęlъ

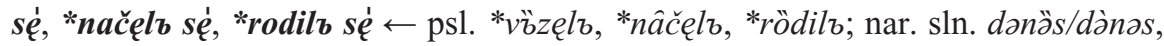

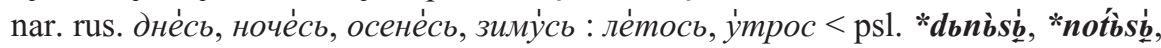

${ }_{6}$ Pred tem je prvi del zakona pojasnjeval t. i. zakon Šahmatova, ki pravi, da se stari cirkumfleks umakne na predslonko (Šahmatov 1901). Tako Šahmatov kot Vasiljev in Dolobko govorijo o premiku naglasa, kar pomeni, da izhajajo iz fonološke naglašenosti oblik. O fonološki nenaglašenosti praslovanskih oblik ob tipološkem sopostavljanju s starogrškimi

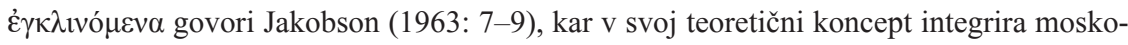
vska naglasoslovna šola (Dybo 2000: 77). 


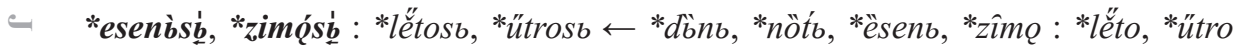

퍼 (Dolobko 1927: 687-693); c) polnopomenska beseda je torej fonetično naglašena

N (s praslovanskim starim cirkumfleksom na prvem zlogu osnove) samo v položaju

- med naglašenima polnopomenskima besedama ali med premoroma, tj. ko se ob njej

त ne pojavljajo breznaglasnice (predslonke in zaslonke) (strus. вóAY : и́ вөАY, за́ вөАY,

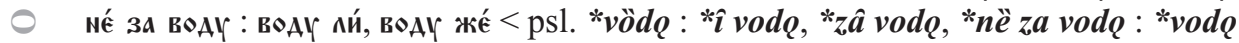

is li, *vodo žé) (Zaliznjak 1985: 372).

Glede na fonološko naglašenost oblike, v kateri se pojavljata, je za praslovanska stara tonema možno reči, da predstavlja praslovanski stari akut avtonomni naglas ( $\mathrm{tj}$. stoji »avtonomno« na fonološko naglašenem zlogu), medtem ko predstavlja praslovanski stari cirkumfleks avtomatični naglas (tj. stoji »avtomatično« na prvem ali zadnjem fonetično naglašenem, a fonološko nenaglašenem zlogu fonološko nenaglašene fonetične besede).

\subsubsection{Praslovanski oblikotvorni naglasni tip b/a}

\subsubsection{Praslovanski oblikotvorni naglasni tip c/a}

Pri glagolih z ničto nedoločniško pripono se pojavlja oblikotvorni naglasni tip c/a, kar pomeni, da glagoli tega tipa v oblikah sedanjiške osnove izkazujejo praslovanski oblikotvorni naglasni tip c, v oblikah nedoločniške osnove pa praslovanski oblikotvorni naglasni tip a (sln. gristi grízeš (grízete), nštok. grïsti grízēš (grízète),

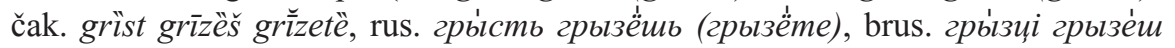
грызяие́, ukr. грйзти гризе́ш гризете́, с̌еš. hrýzt hrýzeš (hrýzete) < psl. *grÿzti *gryzèšb̆ *gryzeté (c/a); sln. žrẹti žrēš žréte, rus. (жрámb) жрёшь (жрёme) < psl. *žêrti *žbrèšb̆ *žbreté (c/a) 'žreti'; sln. píti píješ, nštok. pïti, rus. númb nьёub

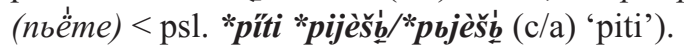

\subsubsection{Praslovanski oblikotvorni naglasni tip d}

Praslovanski oblikotvorni naglasni tip d je značilen samo za nekatere sklanjatvene vzorce (to so moška $o$-jevska sklanjatev, $u$-jevska in $i$-jevska sklanjatev, soglasniška sklanjatev samostalnikov srednjega spola z osnovo na *-es-) in je različica praslovanskega naglasnega tipa b: fonološko nenaglašene oblike imenovalnika/tožilnika ednine, nepremično naglasno mesto na prvem/edinem zlogu končnice v ostalih oblikah (čak. zûb zūbä< psl. *zôbb *zQbà (d) 'zob'; nar. sln. mộst mostä (rezijansko (Bila) 'must mos'tạ) < psl. *möstъ *mostà (d) 'most'; ${ }^{7} \operatorname{sln}$. uhộ ušẹsa < psl. *ûxo

7 V slovenščini odraz psl. naglasnega tipa d izkazuje rezijansko gradivo, kjer je razlika med psl. naglasnima tipoma $\mathrm{b}$ in $\mathrm{c}$ ter hipoteričnim psl. naglasnim tipom d vidna $\mathrm{v}$ odražanju naglasa pri samostalnikih moške $o$-jevske sklanjatve z enozložno osnovo s psl. kratkim sa- 
*ušése (d) : sln. okộ očệsa < psl. *őko *öčese (c)). V večini slovanskih jezikov pa naj bi že zelo zgodaj sovpadel z odrazi praslovanskih naglasnih tipov c ali b (knj. sln. mộst mostû, nštok. môst möst, rus. мócm мócma, češ. most mostu < *möstъ *mösta; sln. zộb zobâ, nštok. zûb zûuba, rus. зy่б зу่бa, češ. zub zubu<*zôbz *zôba). ${ }^{8}$

\subsection{Nepremična naglasna tipa s praslovanskim novim akutom}

Poleg praslovanskega naglasnega tipa a z nepremičnim naglasnim mestom na osnovi se pojavljata še dva nepremična naglasna tipa, ki pa za razliko od tipa a izkazujeta praslovanski novi akut na osnovi, ki ni povsem jasnega nastanka, najverjetneje je pogojen z besedotvornim vzorcem (Dybo 2000: 98). Praslovanska nepremična naglasna tipa s praslovanskim novim akutom izkazujeta tele značilnosti:

(a) nepremično naglasno mesto na osnovi in praslovanski novi akut na dolžini ali na kračini v vseh sklonskih oblikah; imajo ga praslovanski dvozložni samostalniki $\bar{a}$-jevske sklanjatve, izpeljani s praslovanskim priponskim obrazilom *-ja (posledično je zadnji soglasnik osnove jotiran), zanje je torej značilna t. i. »jotacijska imobilizacija« (rus. йотовая иммобилизация): sln. súša súšo, nštok. sûša sûšu, čak. sũša sũšu, rus. cýma cýmy, češ. (souš) souše < psl. *súša *súšQ (a'); sln. kọ́ža kọžo, nštok., čak. köža köžu, rus. кóжa кóжy, češ. kůže kưži < psl. *kòža *kòžQ (a');

(a") nepremično naglasno mesto na osnovi in praslovanski novi akut na kračini v vseh sklonskih oblikah; poznajo ga praslovanski trizložni samostalniki moške $o$-jevske in $\bar{a}$-jevske sklanjatve, izpeljani iz sestavljenih glagolov s pomočjo kvalitativnega prevoja $* e \rightarrow *_{o}$ korenskega samoglasnika, zanje je torej značilna t. i. »prefiksalna imobilizacija« (rus. префиксальная иммобилизация): a) samostalniki moške $o$-jevske sklanjatve: knj. sln. pótok potọka, nar. sln. potök potọka, nštok. pòtok pòtoka, čak. potök potöka, rus. пото́к пото́ка < psl. *potòkr *potòka (a") $\leftarrow$ *potekti *potečešb (c) : psl. *tökb *tökb (c) «*tekti *tečešb (c); b) samostalniki $\bar{a}$-jevske sklanjatve: sln. zalộga zalọgo, nštok. záloga zálogu, češ. záloha zálohu < psl. *zalòga *zalòge $\left(\mathrm{a}^{\prime \prime}\right) \leftarrow{ }^{*}$ zalegti (c).

\subsection{Praslovanski besedotvorni naglasni tipi}

Praslovanski besedotvorni naglasni tipi so značilni za s praslovanskimi produktivnimi priponskimi obrazili izpeljane (za)imenske besedne vrste (samostalnik, pridevnik, zaimek) ter za sedanjiške in nedoločniške glagolske oblike z izjemo sedanjika. Po teoriji moskovske naglasoslovne šole (Dybo 1981: 55-196; 2000: 97-226) je

moglasnikom: rez. sln. 'buk 'boga = knj. sln. bộg bogâ, nštok., čak. bôg böga, rus. бóz бóza $<$ psl. *bögz *böga (c) : rez. sln. 'bọp bo'bạ = knj. sln. böb bóba, nštok. böb bòba, rus. бо́б бобá < psl. *bòbḅ *bobá (b) : rez. sln. 'must mos'tạ < *mösţ *mostá (d). Za hipotetični tip d je bil v rezijanskem narečju slovenščine doslej najdem samo navedeni primer. Rezijanski zgledi so prirejeni po Steenwijk 1992.

${ }^{8} \mathrm{~V}$ posameznih slovanskih jezikih in njihovih narečjih se za psl. naglasni tip d pojavljajo

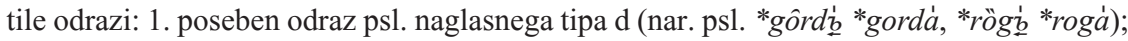
2. sovpad s psl. naglasnim tipom b (nar. psl. *górdb *gordà, *rògz *rogá); 3. sovpad s psl. naglasnim tipom c (nar. psl. *gôrdъ *gôrda, *rögъ *röga) (Dybo - Zamjatina - Nikolajev 1990: 129-154). 
- praslovanščina poznala sedem tovrstnih naglasnih tipov (A, B, C, D, E, F, G), ki imajo tele značilnosti:

(A) stalni staroakutski naglas na besedotvorni podstavi (sln. (stârəc) stârca, nštok. stärac stârca, sr. čak. stärac stãrca, rus. cmápeu cmápųa < psl. *stärbcb *stärbca (A) Ł psl. *stärb (a); sln. (sîlon) sîlna sîlno, nštok. sïlan sïlna sïlno, rus. сильнный< psl. *sílbnъ *sílbna *sílbno $(\mathrm{A}) \leftarrow$ psl. *síla (a); vsl. csl. чи́стота чи́стоту $<$ psl. *črıstota *člstoto $(\mathrm{A}) \leftarrow$ psl. *člstb (a); sln. stárost stárosti, nštok. stärōst stärosti, vsl. csl. ста́рость, rus. cmápocmb cmápocmu < psl. *stärostb *stärosti (A) $\leftarrow$ psl. *stärr (a); sln. ríbica ríbico, nštok. rïbica rïbicu < psl. *rÿbica *rÿbico (A) $\leftarrow$ psl. *rÿba *rÿbo (a); sln. krástav krástava krástavo, nštok. krästav krästava krästavo, rus. корócmabbiŭ< psl. *körstavb *körstava *körstavo (A) $\leftarrow$ psl. *körsta *körsto (a); sln. krâvar krâvarja, nštok. krävār krävārja < psl. *körvaŕb *körvaŕa $(\mathrm{A}) \leftarrow$ psl. *körva *körvo (a));

(B) stalni naglas na prvem/edinem zlogu končnice (sln. zớbəc (zớbca), ${ }^{9}$ nštok.

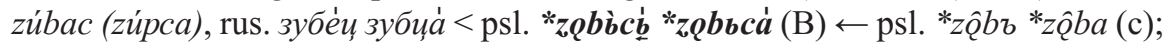

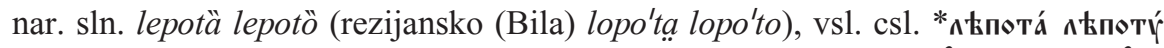
(tip rus. cлепота́ cлenomý) < psl. *lěpotá *lěpotó $(\mathrm{B}) \leftarrow$ psl. *lêpъ *lěpá *le̊po (c) ${ }^{10} \operatorname{sln}$. mesár mesárja, nštok. mèsār mesára, čak. mesãr mesārä < psl. *męsáríb *męsaŕá (B) Ł psl. *męêso (c));

(C) polarizirani mobilni naglas: sln. močân móčna močnộ < psl. *möt́bnb *motbná *mötbno $(\mathrm{C}) \leftarrow$ psl. *mötb (c); sln. mladộst mladộsti, nštok. mlädōst mlädōsti, rus. мо́лодость мо́лодости < psl. *môldostb *môldosti $(\mathrm{C}) \leftarrow$ psl. *môldo *moldá *môldo (c); sln. karvâv (karvâva) karvâvo, nštok. kr̈vāv (kr̈vāva)

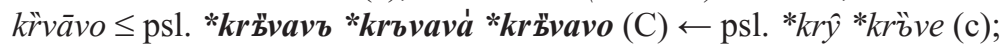

(D) stalni naglas na polglasniku priponskega obrazila: ${ }^{11} \operatorname{sln}$. stólac (stólca), nštok. stòlac (stólca), rus. столе́u (столиа'), ukr. стіле́u (стільияя) : nar. rus., brus. (столлеu) столлиа $\leq$ psl. *stolbcb *stòlbca < *stolbcb *stolbca (D); sln. grẹššn

9 V slovenščini je pri odrazih posameznih samostalnikov na * tipa B prišlo do posplošitve bodisi naglasa imenovalnika (psl. * zobìcb $*_{z} b b c \dot{c}$ (B) $>\sin$. *zóbac *zóbca $\geq$ zó́bac zóbca) bodisi naglasa odvisnih sklonov (psl. *věnb̀cb *věnbcà (B) $>\sin$. *eénac *vénca $\geq$ vénac vénca).

${ }^{10} \mathrm{~V}$ južni slovanščini se v tem tipu prvotno pojavlja odraz praslovanskega naglasnega tipa c

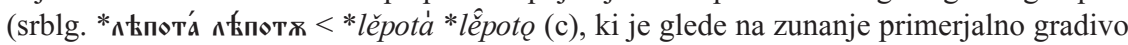
(baltščina) drugoten. Pozneje je v posameznih sistemih prišlo do izravnave naglasa po eni izmed oblik (knj. sln. lepóta lepóto, nštok. ljepòta ljepòtu, lepòta lepòtu z izravnavo po oblikah tipa *lépotá : knj. sln. sirộta sirộto z izravnavo po oblikah tipa *sîroto); redki so primeri z ohranjenim odrazom prvotnega stanja (nar. sln. siróta sirộto (ziljsko (Brdo) saró:ta sarùata) $<*_{\text {sirotá }}^{*}$ sîroto).

${ }^{11} \mathrm{~V}$ pozni praslovanščini je prišlo do naglasnega umika s polglasnika priponskega obrazila $\mathrm{v}$ šibkem položaju in do nastanka poznopraslovanskega novega akuta na edinem/zadnjem zlogu korena. V (zahodni in južni) slovenščini na primer se praslovanski novi akut na kračini v nezadnjem zlogu odraža v samoglasniški kakovosti (sln. žéna : žẹnski, könj : kọ́njski< psl. *žená (b) : *žèn 
grẹ̄šna grẹ́šno < psl. *grěšbnb *grěšbna *grěšsno < *grěšb́nb *grěšb́na *grěšbno (D) $\leftarrow$ psl. *grěxź *grěxá (b);

(E) stalni naglas tipa novega akuta na kratkem samoglasniku priponskega obrazila (sln. dobrọta dobrộto, srblg. Аовро́та Аөвро́тж, vsl. csl. Аөвро́та Аөвро́ту 'dobrota' < psl. *dobróta *dobróte (E) 'dobrota' $\leftarrow$ psl. *dobr'b *dobrà *dobró (b); vzh. srblg. мжарóctи < psl. *mQdróstb *modrósti $(\mathrm{E}) \leftarrow$ psl. *modr'́ *modrá *modró (b);

(F) stalni staroakutski naglas na dolgem samoglasniku priponskega obrazila z dvema podtipoma $z$ naglasnim mestom: $\left(\mathbf{F}_{1}\right)$ na prvem zlogu priponskega obrazila (sln. ženíca ženíco, nštok. žènica žènicu $<$ psl. *ženíca *ženïco $\left(\mathrm{F}_{1}\right) \leftarrow$ psl. *žená *ženò (b); sln. rjāv rjáva rjávo, nštok. r̀đav r̀đava ìđavo < psl. *rbdávb *rbdáva

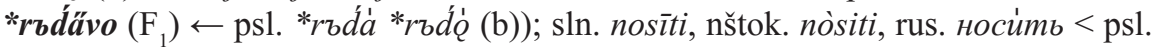
*nosíti $\left(\mathrm{F}_{1}\right) ;\left(\mathrm{F}_{2}\right)$ na predzadnjem zlogu oblike: sln. nožíca nožico, nštok. nòžica nozžicu, čak. nožìca nožīcu < psl. *nožíca *nožíce $\left(\mathrm{F}_{2}\right) \leftarrow$ psl. *nogá *nögQ (c); sln. bradavíca, nštok. bradàvica, nar. rus. бородовйиุa $<$ psl. *bordavíca $\left(\mathrm{F}_{2}\right) \leftarrow$ psl. *bordá *bôrdo (c); sln. morīti, nštok. mòriti, rus. мopúmb < psl. *morïti $\left(\mathrm{F}_{2}\right){ }^{12}$

(G) stalni naglas tipa novega akuta na dolgem samoglasniku priponskega obrazila (sln. konjár konjárja, nštok. kònjār (konjára) < psl. *końáŕb *końáŕa (G) $\leftarrow$ psl. *końb *końa (b)).

Praslovanski besedotvorni naglasni tipi tvorjenk so določljivi na osnovi oblikotvornega naglasnega tipa njihovega besedotvornega predhodnika, tj. pregibne imenske besedne vrste oziroma sedanjika glagola (oblikotvorni naglasni tipi ${ }^{*} a,{ }^{*}$, $*_{c}$ ), in vrste praslovanskega priponskega obrazila. Pri slednjih sta pomembni dve dejstvi: 1. vrsta prvega zložnika priponskega obrazila (polglasnik, kratki samoglasnik, akutirani dolgi samoglasnik, neakutirani dolgi samoglasnik); 2. odsotnost : prisotnost praslovanskega naglasnega tipa $\mathrm{C}$ pri izpeljankah, $\mathrm{tj}$. fonološko nenaglašenih oblik.

\begin{tabular}{|c|c|c|c|c|}
\hline & $* \mathbf{a}$ & $* \mathbf{b}$ & *c & Zgledi \\
\hline psl. $*_{-b-} / *_{-b}$ & $\begin{array}{l}{ }^{*} \mathbf{A} \\
*_{\text {stărbcь }} \\
*_{\text {stärbca }}\end{array}$ & $\begin{array}{l}* \mathbf{D} \\
* \text { stolı́cь } \\
\text { *stòlı́ca }\end{array}$ & $\begin{array}{l}\text { *B } \\
*_{\text {zQbìch }} \\
\text { *zQbbcá }\end{array}$ & $\begin{array}{l}*_{-b c b_{\text {sub }},} *_{-b c a}, *_{-b c e}, \\
*_{-b k b_{\text {sub}},} *_{-} b k a, *_{-} b k o, \\
*_{-b j-}, *_{-b s t v o}\end{array}$ \\
\hline & $\begin{array}{l}\text { *A } \\
\text { *sílbnъ } \\
\text { *sílbna } \\
\text { *sílbno }\end{array}$ & $\begin{array}{l}\text { *D } \\
\text { * grěšb́n } \\
\text { * grě́š́n } \\
\text { * grě́š́n }\end{array}$ & $\begin{array}{l}\text { *C } \\
\text { *möt́snъ } \\
\text { *mot́tbná } \\
\text { *möt́sno }\end{array}$ & $*_{-b n b}, *_{-b k b_{\text {adj }}} *_{-b s k b}$ \\
\hline
\end{tabular}

${ }^{12}$ Razlika med praslovanskima naglasnima podtipoma $\mathrm{F}_{1}$ in $\mathrm{F}_{2}$ je jasno razvidna $\mathrm{v}$ primerih $\mathrm{z}$ zloženim priponskim obrazilom (sln. Brẹzovica : Leskóvica : Bazovica $<*$ bërzovica (A) : *lěskóvica $\left(\mathrm{F}_{1}\right)$ : *bzzovïca $\left(\mathrm{F}_{2}\right) \leftarrow$ psl. *bërza *bërzo (a) : *lěská *lěskè (b) : *büzb *bžza (c)). 


\begin{tabular}{|c|c|c|c|c|}
\hline & \multicolumn{4}{|c|}{$\begin{array}{l}* \mathbf{E} \\
* \text { dobróta } \\
* \text { dobróto }\end{array}$} \\
\hline & $\begin{array}{l}\text { *A } \\
\text { *sta̋rostb } \\
\text { *stärosti }\end{array}$ & $\begin{array}{l}* \mathbf{E} \\
* \text { modróstb } \\
\text { *modrósti }\end{array}$ & $\begin{array}{l}{ }^{*} \mathbf{C} \\
{ }^{*} \text { môldostb } \\
{ }^{*} \text { môldosti }\end{array}$ & $*_{-o s t b}, *_{-o t a}, *_{-o v b}$ \\
\hline \multirow[t]{2}{*}{ psl. *-V̈- } & $\begin{array}{l}\text { *A } \\
* \text { rýbica } \\
\text { *rýbice }\end{array}$ & $\begin{array}{l}\text { *F } \\
\text { *ženíca } \\
\text { *ženíco }\end{array}$ & $\begin{array}{l}\text { *F }_{2} \\
*_{\text {nožíca }} \\
*_{\text {nožíce }}\end{array}$ & $\begin{array}{l}*_{-i c a}, *_{-i n a_{\mathrm{sub}}}, *_{-i s ̌ c ̌ e}, \\
*_{-} a t b, *_{-i t b}\end{array}$ \\
\hline & $\begin{array}{l}\text { *A } \\
\text { *kőrstavъ } \\
\text { *kőrstava } \\
\text { *kőrstavo }\end{array}$ & $\begin{array}{l}\text { *F }_{1} \\
\text { *rbdávъ } \\
\text { *rbdáva } \\
\text { *rъdávo }\end{array}$ & $\begin{array}{l}\text { *C } \\
\text { *krb̈vavъ } \\
\text { *krъvavá } \\
\text { *krb̌vavo }\end{array}$ & $*_{-} e_{n} b, *_{-} a v b, *_{-} e_{-}$ \\
\hline psl. *-V́- & $\begin{array}{l}\text { *A } \\
\text { *kőrvaŕb } \\
\text { *kőrvaŕa }\end{array}$ & $\begin{array}{l}\text { *G } \\
\text { *końáŕr } \\
\text { *końáŕa }\end{array}$ & $\begin{array}{l}\text { *B } \\
\text { *męsáŕr } \\
\text { *męsaŕá }\end{array}$ & $\begin{array}{l}*_{-a r b}, *_{-a k b}, *_{-i k b}, \\
*_{-i n a_{\text {adj }}, *-i n b}\end{array}$ \\
\hline
\end{tabular}

Poznopraslovanski oblikotvorni in besedotvorni naglasni tipi

\subsection{Praslovanska metatonija}

Znotraj praslovanskega naglasnega sistema je opazna besedotvorno pogojena metatonija ali tonemska sprememba v smeri cirkumfleks $>$ akut (natančneje praslovanski stari cirkumfleks na dolžini > praslovanski stari/novi akut na dolžini, praslovanski stari cirkumfleks na kračini > praslovanski novi akut na kračini) in stari akut/ cirkumfleks $>$ prednaglasnost. S stališča fonološke naglašenosti metatoniranega morfema gre za spremembo nenaglašenost (cirkumfleks) > naglašenost (akut) oziroma naglašenost (akut) $>$ nenaglašenost (prednaglasnost). Posledica praslovanske metatonije je prehajanje besedotvorne podstave iz naglasnega tipa $\mathrm{v}$ naglasni tip ob izpeljavi.

Za praslovanščino so značilni tile prehodi med naglasnimi tipi: a) pri izpeljankah s praslovanskimi priponskimi obrazili kot $*_{-} d l o, *_{-j} b, *_{-} v b$ prehod $\mathbf{c}, \mathbf{c} / \mathbf{a} \rightarrow$ b: psl. *žěrti *žbrešb̀ (c/a) 'žreti' : *žerdló (b) ‘žrelo'; psl. *môldb *moldá *môldo (c) 'mlad' : *mold́b *mold́á (b) 'mlaj'; b) pri izpeljankah s praslovanskim priponskim obrazilom *-ja prehod $\mathbf{c} \rightarrow \mathbf{a}^{\prime}$ : psl. *sûxz *suxá *sûxo (c) 'suh' : *súša *súš (a') 'suša'; c) pri izpeljankah iz sestavljenih glagolov in oblik za srednji spol primernika prehod $\mathbf{c} \rightarrow \mathbf{a}, \mathbf{a}^{\prime \prime}: \operatorname{sln}$. vrât vratû, nštok. vrât vrâta, rus. вópom вópoma $<$ psl. *vôrtb *vôrta (c) 'vrat' : sln. obrät obráta, nštok. òbrat òbrata, rus. оборóm оборотma < psl. *obvőrtb *obvörta (a") 'obrat'; sln. tộk (tộka), Npl tokộvi, nštok. tôk (tôka), rus. то́к то́ка, češ. tok toku< psl. *tökb *töka (c) 'tok' : *potòkb *potòka (a") 'potok'; sln. drâg drága dragộ, nštok. drâg drága (drágo), čak. drâg drāgà drâgo, rus. дорог дорога́ дорого < psl. *dôrgъ *dorgá *dôrgo (c) 'drag' : čak. dräže, rus. дороњже< psl. *dőrže (a) 'dražje'. 


\section{Naglasni sistemi baltskih jezikov z zgodovinskojezikoslovnega vidika}

Naglasni sistemi posameznih baltskih jezikov v posameznih naglasnih prvinah izkazujejo sistematične vzporednice, ki jih je mogoče zvesti na skupno prabaltsko izhodišče. Naglasno mesto se ujema v litovščini in stari pruščini (lit. móte 'zakonska žena', añtras antrà 'drugi, drug', turéti 'imeti', kadà 'kdaj, kadar', dabar̃ 'zdaj' = stpr. mūti 'mati', anters antrā 'drug', turìt 'imeti', kadden 'kdaj, kadar', dabber 'še'), ${ }^{13}$ letonskemu lomljenemu tonemu ustreza v litovščini (in stari pruščini) akutirani prednaglasni zložnik (let. gâlva 'glava', $\hat{a} z i s$ 'kozel', sîrds 'srce' : lit. galvà 'glava', ožỹy 'kozel', širdìs 'srce' (: Asg gálva, óžiq, širdi) < pblt. *gál'váa, *ááż̃̄is, *śír'dis). Tonemi so vzporedni v litovščini in v letonščini v prvem zlogu (lit. dúona 'kruh', líepa 'lipa', brólis 'brat', mótè 'mati', sáule 'sonce' : draũgas 'prijatelj', Asg aũsį 'uho', Asg žiẽma 'zima' = let. duõna 'kos kruha', liẽpa 'lipa', brẫlis 'brat', mã̃te 'mati', saũle 'sonce' : dràugs 'prijatelj', Asg àusi 'uho', Asg zìemu 'zima' <

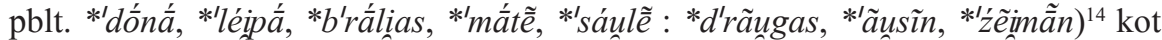
tudi v stari pruščini, ko so le-ti posredno označeni (na dvoglasnikih in dvoglasniških zvezah) (stpr. Asg m aīnan 'eden', pogaūt 'ujeti, zgrabiti', Apl kaūlins 'kost', Asg m geīwan 'živ', boūt 'biti', Asg soūnon 'sin' : èit 'iti', Asg fwāig/tan 'zvezda', Apl āusins 'uho', ìmt 'vzeti', desīmts 'deseti' = lit. Asg m viena, pagáuti, káulas, Asg m gýva, búti, Asg sínnu : eĩti, Asg žvaĩgždę, Asg aũsí, im̃ti, dešiñtas < pblt.

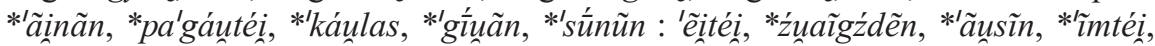
*de'símtas). ${ }^{15}$

Nobeden od dokumentiranih baltskih jezikov ne ohranja prvotnega prabaltskega naglasnega stanja, v vsakem od njih je prišlo do naglasnih sprememb.

\subsection{Litovščina}

$\mathrm{V}$ litovskem naglasnem sistemu je prišlo do regularnih naglasnih sprememb (naglasni pomik po drugem de Saussurjevem zakonu, krajšanje izglasnih dolžin po Leskienovem zakonu, daljšanje v naglašenih odprtih nezadnjih zlogih, navzkrižna metatonija) in analognih sprememb (naglasnomestne izravnave znotraj pregibalnih vzorcev, prehajanje leksemov iz naglasnega tipa v naglasni tip).

${ }^{13} \mathrm{~V}$ tretjem staropruskem katekizmu (Enchiridion, 1561) je na naglasno mesto mogoče sklepati na osnovi dveh grafičnih posebnosti: 1. znak ${ }^{\text {( }}$ (v transliteraciji ${ }^{-}$) označuje naglašenost enoglasnika in dvoglasnika ter samoglasnika v dvoglasniški zvezi; 2. pisni dvojni soglasniki nakazujejo, da je samoglasnik levo od njih kratek in nenaglašen ter posledično kažejo na to, da se naglasno mesto nahaja v sledečem zlogu.

${ }^{14}$ Naglasna znamenja v vzhodnobaltskih jezikih: a) litovščina: $V$ (naglasno mesto, dolžina, litovski zgodovinski akut), $\breve{V}$ (naglasno mesto, dolžina, litovski zgodovinski cirkumfleks), $\grave{V}$ (naglasno mesto, kračina); b) letonščina: $\grave{V}$ (dolžina, letonski rastoči tonem), $\grave{V}$ (dolžina, letonski padajoči tonem), $\hat{V}$ (dolžina, letonski lomljeni tonem).

${ }^{15}$ Označevanje tonemov v stari pruščini: 1. znak na drugi sestavini dvoglasnika označuje staropruski rastoči tonem; 2. znak na prvi sestavini dvoglasnika ali na prvi sestavini dvoglasniše zveze označuje staropruski padajoči tonem. 
Naglasni pomik po drugem de Saussurjevem zakonu: Prabaltsko naglasno mesto se je v litovščini s prabaltskega cirkumflektiranega ali kratkega zložnika pomaknilo na neposredno sledeči prabaltski akutirani zložnik (de Saussure 1896: 157) (lit. krūmas (1) 'grm', lãpas (2) 'list' $\rightarrow$ krūmuotas 'grmičast' : lapúotas 'listnat' < pblt. *k'rúmótas (I/1), *'lapótas (I/2); lit. septynì (3) 'sedem', Apl septýnius < pblt.

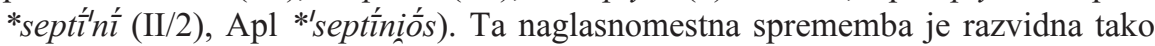
znotrajsistemsko (lit. výras (1) 'mož, moški, soprog', piřštas (2) 'prst', kélmas (3) 'deblo, steblo', diẽvas (4) 'bog' : Ipl výrais, piřštais : kelmaĩs, dievaĩs : Apl výrus, kélmus : pirštùs, dievùs < pblt. Apl *lừiráns, *'kélmáns, *'pĩrštáns : *'dẽiúnáns) kot zunajsistemsko v primerjavi s staropruskim gradivom (lit. Apl rankàs 'roke', Apl ausis 'ušesa' : stpr. Apl rānkans ['rãnkans] 'roke', Apl āusins ['ãusins] 'ušesa' < pblt. *'rãnkáns, *'ãusíns).

Krajšanje izglasnih dolžin po Leskienovem zakonu: a) Prabaltski (nenaglašeni in naglašeni) akutirani zložniki v (odprtem in zaprtem) zadnjem zlogu so se v litovščini skrajšali (lit. várna 'vrana', galvà 'glava', Nsg f tà 'ta' < pblt. *'uárnà, *gál'uấ, *'tấ); b) Prabaltski (nenaglašeni in naglašeni) cirkumflektirani zložniki v (odprtem in zaprtem) zadnjem zlogu so v litovščini ostali dolgi (lit. Gsg várnos,

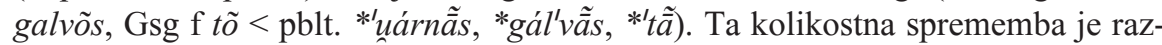
vidna tudi znotrajsistemsko (lit. gẽras (4) 'dober', Nsg f indef. gerà : def. geróji,

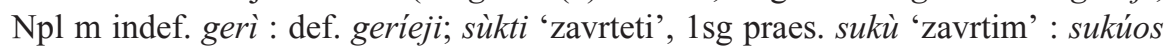
'zavrtim se', 2sg praes. suki 'zavrtiš' : sukies 'zavrtiš se').

Daljšanje v naglašenih odprtih nezadnjih zlogih: Prabaltska kratka *e, *a v naglašenih odprtih nezadnjih zlogih sta se v litovščini podaljšala, kar je razvidno tudi znotrajsistemsko (lit. nèšti 'nesti' : 3sg praes. nẽša < plt. *neś'téi 'nesti' : 3sg praes. *'neśa; lit. avis 'ovca' : Asg ãvi<< pblt. *au'is : *'auin).

Navzkrižna metatonija: V litovščini je prišlo do navzkrižne metatonije: prabaltski akut, tj. rastoči tonem, se je spremenil v litovski padajoči tonem, prabaltski cirkumfleks, tj. padajoči tonem, se je spremenil v litovski rastoči tonem. Poimenovanje litovskih tonemov je zato samo zgodovinsko (zgodovinski akut, zgodovinski cirkumfleks). Litovska navzkrižna metatonija je razvidna zunajsistemsko v primerjavi z letonskim in staropruskim gradivom. ${ }^{16}$

Analogne spremembe: Pri fonološko nenaglašenih oblikah je v sklanjatvi prišlo do izravnave naglasa po oblikah brez naslonke (lit. Asg gálva 'glavo', põ gál-

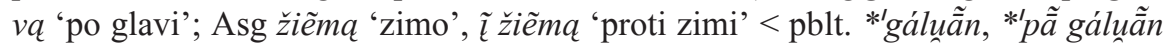

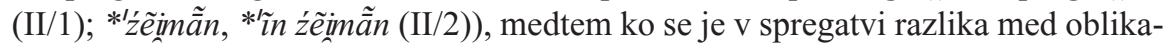
mi brez naslonke in oblikami z naslonko pri glagolih s cirkumflektiranim ali kratkih

${ }^{16}$ Razliko v tonskem poteku jasno nakazujejo naglasna znamenja na dvoglasnikih in dvoglasniških zvezah: 1. naglasno znamenje na prvi sestavini kaže na padajoči tonski potek (lit. dúona, pagáuti, let. dràugs, stpr. ēit); 2. naglasno znamenje na drugi sestavini kaže na rastoči tonski potek (lit. draũgas, eĩti, let. duõna, stpr. pogaūt).

Podoben pojav navzkrižne metatonije v slovanskih jezikih srečamo v križevško-podra-

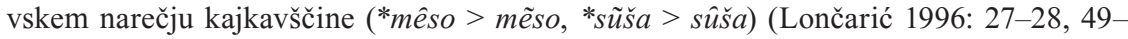
50), v predzadnjih besednih zlogih pa tudi v poljanskem narečju slovenščine (*brẹ́:za > brẹ̀za, *sẹ:nca > sẹ́:nca) (Stanonik 1977: 298). 
zložnikom v korenu (pri katerih ni prišlo do naglasnega pomika s predslonke na koren po de Saussurjevem zakonu) ohranila (lit. dúoda 'dá', nedúoda 'ne dá', atdúoda 'oddá', let. duôd 'dá', neduôd 'ne dá', atduôd 'oddá' : lit. nẽša 'nese', nèneša 'ne nese', àtneša 'odnese' < pblt. *'dóda, *'ne dóda, *'at dóda (II/2); *'neśa, *'ne neśa, *'at neśa (II/2)). V knjižni litovščini sta skozi zgodovino dokumentirani predvsem težnji po prehodu leksemov med naglasnimi tipi kot $1 \geq 3$ in $2 \geq 4$, pri čemer inovacijo potrjuje tudi primerjava s stanjem v letonščini, redkeje v stari pruščini (lit. pilnas pilnà $(3) \leq$ stlit. pillnas pìlna (1) 'poln', let. pi îns pi lna 'poln' < pblt. *'pílnas

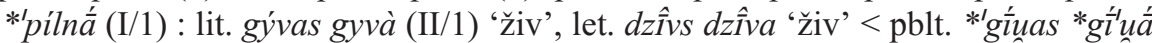

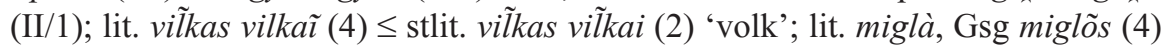
$\leq$ stlit. miglà, Gsg miglos (2) 'megla' < pblt. *'miglấ, Gsg *'miglẫs (I/2); lit. ãštras aštrà (4) $\leq$ stlit. ãštras aštrà (2) 'oster').

\subsection{Letonščina}

$\mathrm{V}$ letonskem naglasnem sistemu je prišlo do regualrnih naglasnih sprememb (posplošitev naglasnega mesta na prvem zlogu, krajšanje v zadnjih zlogih večzložnic) in analognih sprememb (tonemske izravnava znotraj pregibalnih vzorcev).

Posplošitev naglasnega mesta na prvem zlogu: V letonščini je (verjetno pod vplivom substratnih in adstratnih baltofinskih jezikov, ki poznajo stalno naglasno mesto na prvem zlogu) prišlo do posplošitve naglasnega mesta na prvem zlogu. Letonski umično naglašeni zložniki imajo tele toneme: a) prabaltski akutirani prednaglasni zložnik (znotraj prabaltskega mobilnega naglasnega podtipa II/1) ima letonski lomljeni tonem (let. 'gal̂lva 'glava', lit. galvà, Asg gálva< pblt. *gál'uấ); b) prabaltski cirkumflektirani prednaglasni zložnik (znotraj prabaltskega mobilnega naglasnega podtipa II/2) ima letonski padajoči tonem (let. 'zìema 'zima', lit. žiemà, Asg žiẽma < pblt. *źé̃ímá) .

Krajšanje v zadnjem zlogu večzložnic: Prabaltski dolgi zložniki v zadnjem zlogu večzložnic so se v letonščini skrajšali (let. vã̃rna 'vrana', Gsg vã rnas, lit. várna 'vrana', Gsg várnos < pblt. *'uárná , Gsg *'uárnã s; 1-3sg praes. let. saku saki saka 'reči', lit. sakaũ sakaĩ sãko < pblt. *sa'kãu *sa'kãi ${ }^{*} s a$ 'kã ; let. labi 'dobro', lit. labaĩ 'zelo, dobro' < pblt. *la'bãi), v zadnjem zlogu enozložnic pa so ostali dolgi (let. Nsg f $t \tilde{\bar{a}}$ 'ta', Gsg f $t \grave{\bar{a}}$, lit. Nsg f tà, Gsg f tõ $<$ pblt. Nsg f $*^{\prime} t \bar{a}$, Gsg f $* t$ ta ; let. Apl mũ $s$ 'mi', lit. mùs < pblt. *'míns; let. Apl trî̀s 'trije', lit. trìs < pblt. *t'rís), oboje ne glede na prabaltski tonem zložnika v zadnjem zlogu.

Izravnava tonemov znotraj pregibalnih vzorcev: V letonščini je na prvem zlogu prišlo do posplošitve enega od tonemov (letonščina posledično na prvem zlogu ne pozna tonemskih premen). Pri odrazu prabaltskega mobilnega naglasnega podtipa II/1 se je na primer posplošil lomljeni tonem v prvotno fonetično naglašenih oblikah, v katerih bi pričakovali rastoči tonem (let. 'gal̂lva 'glava', Asg 'gâेvu : lit. galvà, Asg

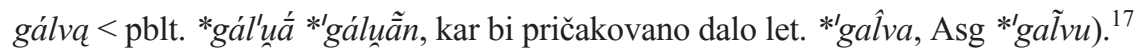

${ }^{17}$ Do tipološko podobne izravnave naglasnih prvin pri odrazih samostalnikov praslovanske $\bar{a}$-jevske sklanjatve naglasnega tipa c z dolžino v osnovi je prišlo tudi v zahodnoslovanskih jezikih, kjer je bila v oblikah s pričakovano dolžino posplošena kračina (češ. hlava hlavu, slš. hlava hlavu, polj. głowa głowe, gluž. hłowa hłowu brez kolikostne premene za 
$-\quad 2.3 \quad$ Stara pruščina

V stari pruščini je prišlo do ene regularne naglasne spremembe (naglasni pomik po Kortlandtovem zakonu).

Naglasni pomik po Kortlandtovem zakonu: Prabaltsko naglasno mesto se je v stari pruščini s prabaltskega kratkega naglašenega zložnika pomaknilo na neposredno sledeči zložnik (ne glede na njegove naglasne značilnosti) (Kortlandt 1974: 302) (stpr. Asg buttan [bu'tan] 'hiša', dessimton [de'simton] 'deset', Asg gallan [ga'lan] 'smrt', 2pl praes. immati [i'mati] 'vzamete', Asg m labban [la'ban] 'dober', semmē [ze'mē] 'zemlja' : lit. Asg bùta 'stanovanje', dẽšimt 'deset', Asg gãla 'konec', 2 pl praes. ìmate 'vzamete', Asg m lãbq 'dober', žẽmè 'zemlja' < pblt. *'butãn, *'deśimt, *'galãn, *'imatề, *'labãn, *'źemẽ $).{ }^{18}$

\section{Prabaltoslovanski naglasni sistem}

Za prabaltoslovanski naglasni sistem se navadno trdi, da je bil istoveten s prabaltskim. ${ }^{19}$ To pomeni, da ga je mogoče rekonstruirati na osnovi naglasnega stanja v baltskih jezikih, ki izkazujejo bolj arhaično naglasno stanje od slovanskih jezikov. Rekonstrukcija prabalt(oslovan)skih naglasnih tipov s pomočjo primerjalne metode in metode rekonstrukcije je osnova za tvorbeno-pretvorbeno predstavitev naglasnih značilnosti določenih morfemov posameznih oblik pregibnih besednih vrst $\mathrm{v}$ okviru teorije naglasne valence morfemov in postavitev pravila o določanju prabalt(oslovan)skega naglasnega mesta.

pričakovano češ. *hláva *hlavu, slš. *hláva *hlavu, polj. *główa *głowę, gluž. *hłówa *hłowu kot odraz psl. *goluá *gôlue (c) (> sln. gláva glavộ, nštok. gláva glâvu, čak. glāvä glâvu, rus. голова́ го́лову)).

${ }^{18}$ Do naglasnega pomika v stari pruščini po Kortlandtovem zakonu je prišlo ne glede na fonološko naglašenost prabaltskega fonetično naglašenega zloga in ne glede na kolikost ali tonem zložnika v ponaglasnem zlogu. Do staropruskega naglasnega pomika pride torej pod drugačnimi pogoji kot do litovskega pomika po drugem de Saussurjevem zakonu in do praslovanskega pomika po Dybojevem zakonu.

${ }^{19}$ Istovetnost prabaltskega in prabaltoslovanskega naglasnega sistema je značilna predvsem za strukturo naglasnega sistema kot celote, razlike pa se lahko pojavljajo pri strukturiranosti in naglasu posameznih oblik: 1 . oblikovne razlike: 2 pl praes. psl. *jbmete 'vzamete' < *im-e-te : lit. imate 'vzamete', stpr. immati [i'mati] < *im-a-tē; 2. naglasne razlike: psl. *nesti 'nesti' : lit. nèsti 'nesti'; psl. Npl *mếsi 'mehovi' : lit. maišaĩ 'vreče'; psl. Nsg *nötb 'noč', Gsg *nöti, Asg *nötb: lit. Nsg naktìs 'noč', Gsg naktiẽs : Asg nãktí; psl. Nsg *sŷnъ 'sin', Gsg *sŷnu, Asg *sŷnъ : lit. Nsg sūnùs 'sin', Gsg sūnaũ, Asg sùnnu. Glede na to, da v slednjih primerih baltščina izkazuje več različno naglašenih oblik, je bolj verjetno, da je do analognih izravnav prišlo v slovanščini (na primer izravnava naglasa imenovalnika po naglasu tožilnika po vzoru samostalnikov $o$-jevske sklanjatve). 


\subsection{Prabaltoslovanski naglasni tipi}

Za rekonstrukcijo prabaltoslovanskih naglasnih tipov je najbolj povedno litovsko gradivo, zgodovinskojezikoslovno interpretirano z upoštevanjem litovskih naglasnih in analognih sprememb (prim. 2.1). Letonsko in staroprusko gradivo prabaltsko rekonstrukcijo na osnovi litovskega gradiva potrjujeta oziroma jo ponekod nekoliko modificirata: letonščina $\mathrm{v}$ primerih, ko je v litovščini prišlo do analognih sprememb (prim. 2.2); stara pruščina v primerih, ko je v litovščini prišlo do naglasnega pomika po de Saussurjevem zakonu (prim. 2.3).

Prabaltoslovanščina je poznala dva osnovna naglasna tipa (I, II), ki sta glede na tonem naglašenega zložnika v osnovi imela vsak po dva naglasna podtipa (I/1, $\mathrm{I} / 2, \mathrm{II} / 1, \mathrm{II} / 2)$.

Prabaltoslovanski nemobilni naglasni tip (I) je imel nepremično naglasno mesto na osnovi (osnova je torej vsebovala vsaj en fonološko naglašeni morfem, in sicer koren ali priponsko obrazilo) ter je imel dva naglasna podtipa: A) s prabaltoslovanskim akutiranim zložnikom v osnovi (I/1): a) naglasno mesto je bilo na korenu $\left(\mathbf{I} / \mathbf{1}_{\mathbf{R x}}\right) ;$ b) naglasno mesto je bilo na priponskem obrazilu $\left.\left(\mathbf{I} / \mathbf{1}_{\mathbf{S X}}\right) ; \mathrm{B}\right)$ s prabaltoslovanskim cirkumflektiranim ali kratkim zložnikom v osnovi (I/2): a) naglasno mesto je bilo na korenu $\left(\mathbf{I} / \mathbf{2}_{\mathrm{Rx}}\right)$; b) naglasno mesto je bilo na priponskem obrazilu $\left(\mathrm{I} / \mathbf{2}_{\mathrm{Sx}}\right)$.

Prabaltoslovanski mobilni naglasni tip (II) je imel fonološko naglašene oblike z naglasnim mestom na edinem/zadnjem zlogu končnice in fonološko nenaglašene oblike s fonetičnim naglasnim mestom na prvem ali zadnjem zlogu fonološke besede (osnova je torej vsebovala samo fonološko nenaglašene morfeme) ter je imel dva podtipa: A) s prabaltoslovanskim akutiranim zložnikom v korenu (II/1); B) s prabaltoslovanskim cirkumflektiranim ali kratkim zložnikom v korenu (II/2).

\subsection{Naglasna valenca morfemov}

Rekonstruirani prabaltoslovanski naglasni sisetm je mogoče predstaviti na tvorbenopretvorbeni način v okviru teorije naglasne valence morfemov. Jedro teorije je, da ima vsak morfem neke oblike pregibne besedne vrste naglasno valenco, in sicer je morfem: 1. naglasno dominanten, $\mathrm{tj}$. $\mathrm{z}$ naglasno valenco »plus« $(+)$, če je fonološko naglašen; 2. naglasno recesiven, $t j$. $z$ naglasno valenco »minus « (-), če je fonološko nenaglašen. Naglasno valenco so imeli vsi morfemi (korenski, besedotvorni, končniški). ${ }^{20}$

\subsubsection{Korenski morfemi}

Prabaltoslovanski korenski morfemi so bili naglasno dominantni ali naglasno recesivni:

${ }^{20}$ Moskovska naglasoslovna šola na tvorbeno-pretvorbeni način v okviru teorije naglasne valence morfemov opisuje tudi naglasne sisteme manj raziskanih sodobnih jezikov (na primer abhazijščine, kavkaškega jezika severozahodne podskupine; Dybo 2000: 660734). 
A) naglasno dominantni koreni so bili značilni za prabaltoslovanski nemobilni naglasni tip z naglasnim mestom na korenu $\left(\mathrm{I}_{\mathrm{Rx}}\right)$, in sicer: a) akutirani naglasno dominantni koreni za naglasni podtip I/1 (lit. vilna vilna (1) 'volna', let. vil̃na

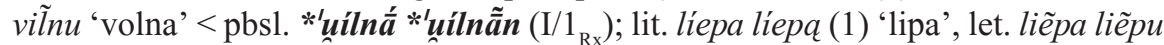

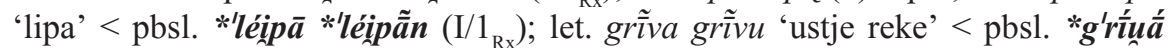
*g'rîú $\tilde{\bar{a} n}\left(\mathrm{I} / 1_{\mathrm{Rx}}\right)$; lit. dúona dúona (1) 'kruh', let. duõna duõnu 'krajec kruha' < pblt.

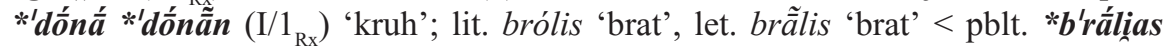
$\left(\mathrm{I} / 1_{\mathrm{Rx}}\right) ;{ }^{21}$ lit. dúmmai pl. (1) 'dim', let. dũmi pl. 'dim' < pbsl. *'dúmã̃i pl. (I/1 $\left.1_{\mathrm{Rx}}\right)$; lit. pilnas pilnà $(3 \leq 1)$ 'poln', let. pi lns pi lna 'poln' < pbsl. *'pílnas *'pílnāa $\left.\left(\mathrm{I} / 1_{\mathrm{Rx}}\right)\right)$;

b) cirkumflektirani ali kračinski naglasno dominantni koreni za naglasni podtip $\mathrm{I} / 2$ (lit. blusà blùsq (2) 'bolha', let. blusa blusu < pbsl. *b'lus ấ *b'lus $\tilde{\tilde{a}} \boldsymbol{n}\left(\mathrm{I} / 2_{\mathrm{Rx}}\right)$; lit. žam̃bas $(4 \leq 2)$ 'rob, nekaj ostrega', let. zùobs 'zob' < pbsl. *źãmbas $\left(\mathrm{I} / 2_{\mathrm{Rx}}\right)$ 'zob'; lit. pãdas (2) 'podplat, pod, spodnji del', let. pads 'tlak, pod' < pbsl. *'padas $\left(\mathrm{I} / 2_{\mathrm{Rx}}\right)$ 'pod, tla'; lit. ãštras aštrà $(4 \leq 2)$ 'oster', let. astrs astra 'oster' < pbsl. *'aśtras *'aśtrấ (I/2 $\left.{ }_{\mathrm{Rx}}\right)$ 'oster');

B) naglasno recesivni koreni so bili značilni za prabaltoslovanski nemobilni naglasni tip $\mathrm{z}$ naglasnim mestom na priponskem obrazilu $\left(\mathrm{I}_{\mathrm{Sx}}\right)$ (prim. 3.2.2) in za prabaltoslovanski mobilni naglasni tip (II), in sicer: a) akutirani naglasno recesivni koreni za naglasni podtip II/1 (lit. galvà gálva (3) 'glava', let. gâlva gal̂̀u < pbsl.

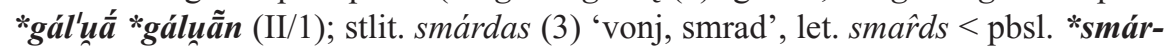

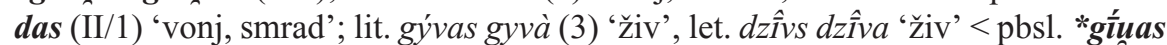
*gî̀'uấ (II/1); lit. núogas nuogà (3) 'nag', let. nuôgs nuôga 'nag' < pbsl. *nốgas *nó' $g \bar{a}(\mathrm{II} / 1))$; b) cirkumflektirani ali kračinski naglasno recesivni koreni za na-

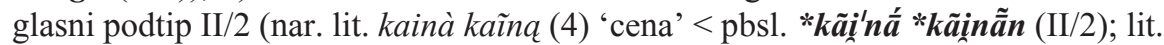

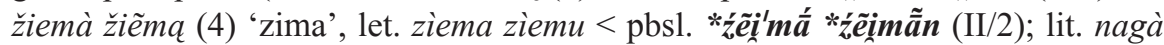
nãga (4) 'kopito' < pbsl. *na'gã * $\boldsymbol{n a g} \tilde{\tilde{a} \boldsymbol{n}}$ (II/2) 'nohti, noga'; lit. maĩšas maišã (4) 'vreča', let. màiss màisi 'vreča' < pbsl. *mãĭšas *mãilšãa (II/2) 'meh, vreča'; lit. saũsas sausà (4) 'suh', let. sàuss sàusa 'suh' < pbsl. *sãunsas *sãúc'sá (II/2); lit. bãsas basà (4) 'bos', let. bass basa 'bos'< pbsl. *basas *ba'sấ (II/2)).

\subsubsection{Besedotvorni morfemi}

Prabaltoslovanski besedotvorni morfemi, od katerih so tu obravnavana samo priponska obrazila, so bili naglasno dominantni, drugotno dominantni, recesivni.

Naglasno dominantna priponska obrazila so spreminjala naglasno valenco neposredno pred seboj stoječih morfemov, naglasno recesivni morfem je namreč postal naglasno drugotno dominantni morfem, pri čemer se je prabaltoslovanski recesivni akut metatoniral $\mathrm{v}$ dominantni cirkumfleks. Tovrstna priponska obrazila so bila: lit. -tas, -stas, -klas, -vas, -kas < ie. *-tó-, *-stó-, *-tló-, *-uó-, *-kó- ${ }_{\text {sub }}$ (lit. déti 'položiti', let. dêt' 'leči jajca' : lit. dẽklas 'prevleka, ovoj' < pblt. *déttéi (II/1) :

${ }^{21}$ Oblika lit. brólis 'brat', let. brã lis 'brat' < pblt. *b'rá̆lias (I/1) je (vzhodno)baltska inovacija, odraz prvotne oblike je posredno ohranjen v izpeljankah lit. broterẽlis 'bratec', bróterautis 'bratiti se' $\leftarrow$ pblt. * $b^{\prime} r a ̂ ́ t e \tilde{r}(\mathrm{I} / 1)$, pri čemer je prvotni naglas ohranjen v lit. bróterautis. 
*'dẽttlãn (I/2) < *détlãn (II/1)); psl. *-dlo, *-jb, *-vb < ie. *-tló-, *-ió-, *-uó- (psl. *žérti *žbrešb (c/a) ‘žreti’ : *žerdló (b) ‘žrelo’ < pbsl. *gér'téi (II/1) : *'gẽrtlãn (I/2) < *gértlãn (II/1)) (Dybo - Zamjatina - Nikolajev 1990: 8899).

Naglasno drugotno dominantna priponska obrazila (za razliko od naglasno prvotno dominantnih) spremembe naglasne valence neposredno pred seboj stoječih morfemov niso povzročala. Tovrstna priponska obrazila so bila: a) akutirana naglasno drugotno dominantna priponska obrazila: lit. -uotas, -ytis, -iena < ie. *-ō-tó-, *-ì-tió-, *-èi-ná (stlit. miltuotas miltuota 'mokast', dumblúotas dumblúota 'muljast, blaten', taukúotas taukúota 'masten', kraujúotas kraujúota 'kr-

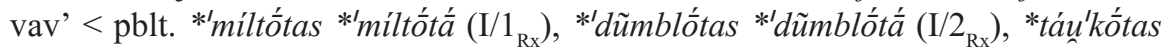

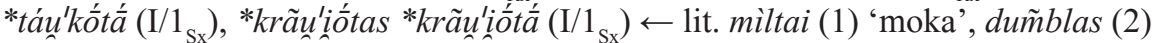
'mulj, blato', taukaĩ (3) 'mast', kraũjas (4) 'kri' < pblt. *'míltas (I/1), *'dũmblas (I/2), *táukas (II/1), *krãuias (II/2)); psl. *atb, *itb, *ica, *-ina ${ }_{\text {sub, }}$ *-išče < ie.

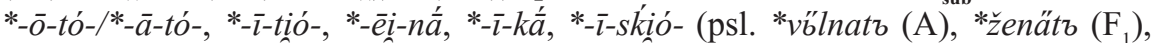
*bordätr $\left(\mathrm{F}_{2}\right)=$ *męsätica $(\mathrm{F})^{22} \leftarrow$ *vólna (a), *žená (b), *bordá (c), *męso (c)); b) cirkumflektirana ali kračinska naglasno drugotno dominantna priponska obrazila: lit. -ybé, -okas, -ykas, -inykas ( $\geq$-ininkas); -ikas, -ukas ${ }_{\mathrm{sub}}$, -is, -inis, -tuvas, -ata

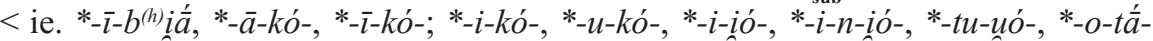
(stlit. príešinykas 'nasprotnik', viẽtinykas 'namestnik', darbinỹkas 'delavec',

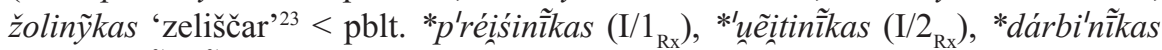
$\left(\mathrm{I} / 2_{\mathrm{Sx}}\right)$, *źäli'ñ̄̄kas $\left(\mathrm{I} / 2_{\mathrm{Sx}}\right) \leftarrow$ lit. príešas (1) 'sovražnik', vietà (2) 'mesto, prostor, kraj', dárbas (3) 'delo', žolẽ (4) 'trava, zelišče' < pblt. *p'réiśas (I/1), *uễitá

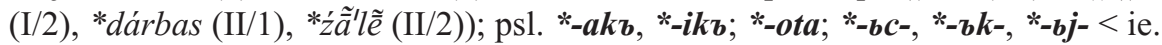
*-ō-kó-/*-ā-kó-, *-i-kó-, *-o-tá-, *-i-kó-, *-u-kó-, *-i-ió- (psl. *stärbcb (A), *stolbcb (D), *zobbcb (B) « *stärb (a), *stolib (b), *zôbb (c)).

Naglasno recesivna priponska obrazila so bila: a) akutirana: lit. -yba, -ingas, -okas $<*_{-}-\overline{-}-b^{(h)} \bar{a}, *_{-}-g_{-}^{(h)} o_{-},{ }^{*}-\bar{a}-k o ́-$ (stlit. ilgokas ilgoka 'malo dolg', mažókas mažóka 'majcen', šáltokas šaltokà 'mrzlkast', retókas retokà 'redkast' <

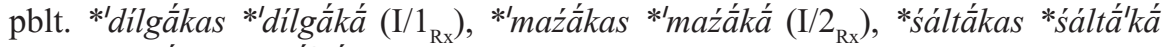
(II/1), *retấkas *retá'ká $(\mathrm{II} / 2) \leftarrow$ lit. ilgas ilgà $(3 \leq 1)$ 'dolg', mãžas mažà $(4 \leq$ 2) 'majhen', šáltas šaltà (3) 'mrzel', rẽtas retà (4) 'redek' < pblt. *'dílgas *'dílgáa (I/1), *'maźas *'maźá (I/2), *śáltas *śál'tá (II/1), *retas *re'táa (II/2)); psl. *avz,

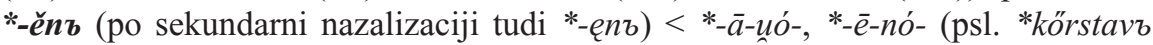
(A), *rzdávb $\left(\mathrm{F}_{1}\right)$, *krb̈vavb (C) : *bordavïca $\left(\mathrm{F}_{2}\right) \leftarrow$ psl. *körsta (a), *rbd́a (b), *krŷy *krüve (c), *bordá (c)); b) cirkumflektirana ali kračinska: lit. -inas, -uka$\boldsymbol{s}_{\text {adj' }},-i \check{s} k a s,-a s t i s<$ ie. *-i-no-, *-u-ko-, *-is-ḱo-, *-os-ti- (lit. výriškas výriška 'moški', dvãsiškas dvãsiška 'duhoven, duševen', súniškas sūniškà 'sinovski', diẽviškas

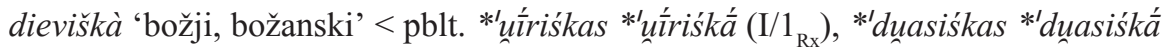
$\left(\mathrm{I} / 2_{\mathrm{Rx}}\right)$, * súuniśkas *sūniś'ká (II/1), *dẽiuiśkas *dẽiuiś'ká (II/2) 世 lit. výras (1) 'mož', dvãsas (2) 'duh, duša', sūnùs (3) 'sin', diẽvas (4) 'bog'< pblt. *'ư⿱⺈⿵aras (I/1), *'duasas

${ }^{22}$ Sln. mesática 'vrsta ribe' (SSKJ) < psl. *męsätica $(\mathrm{F})$.

${ }^{23} \mathrm{~V}$ sodobni litovščini se izpeljanke glasijo: priešininkas 'nasprotnik', viẽtininkas 'namestnik', darbiniñkas 'delavec', žoliniñkas 'zeliščar'. 
— (I/2), *sū'nus (II/1), *dẽiuas (II/2)); psl. *-bnb, *-bkb adj, *-bskb, *-ostb < ie. *-i-no-,

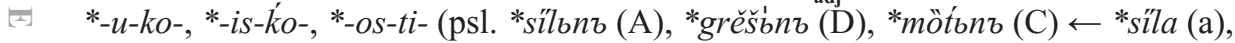

N *grěxb̆ (b), *mötb (c)).

\subsubsection{Končniški morfemi}

Prabaltoslovanski končniški morfemi so bili naglasno dominantni ali naglasno recesivni: A) prabaltoslovanske naglasno dominantne končnice so bile v prabaltoslovanskem mobilnem naglasnem tipu (II) naglašene; B) prabaltoslovanske naglasno recesivne končnice so bile v prabaltoslovanskem mobilnem naglasnem tipu (II) nenaglašene.

\subsection{Prabaltoslovansko naglasno mesto}

Tipološko gledano je imela prabaltoslovanščina stalno naglasno mesto, in sicer na prvem naglasno dominantnem morfemu od začetka besede: 1. oblika je imela naglasno mesto na korenu in posledično naglasni tip $I_{R x}\left(I / 1_{R x}, I / 2_{R x}\right)$, če je bil korenski morfem naglasno dominanten, pri čemer sta bila priponski in končniški morfem lahko naglasno dominantna ali naglasno recesivna: pbsl. ${ }^{*} \mathbf{R} \mathbf{x}_{(+)}-\mathbf{S x}-\mathbf{T e r}$ $\left(\mathbf{I}_{\mathrm{Rx}}\right)$; 2. oblika je imela naglasno mesto na priponskem obrazilu in posledično naglasni tip $\mathrm{I}_{\mathrm{Sx}}\left(\mathrm{I} / 1_{\mathrm{Sx}}, \mathrm{I} / 2_{\mathrm{Sx}}\right)$, če je bil korenski morfem naglasno recesiven in priponski morfem naglasno dominanten (natančneje drugotno dominanten (prim. 5.4)), pri čemer je bil končniški morfem lahko naglasno dominanten ali naglasno recesiven: pbsl. * $\mathbf{R} \mathbf{x}_{(-)}-{ }^{\prime} \mathbf{S} \mathbf{x}_{( \pm)}-\mathbf{T e r}\left(\mathbf{I}_{\mathbf{S x}}\right)$; 3. oblika je imela naglas na končnici in posledično naglasni tip II (II/1, II/2), če sta bila korenski in priponski morfem naglasno recesivna, končniški morfem pa naglasno dominanten: pbsl. ${ }^{*} \mathbf{R} \mathbf{x}_{(-)}-\mathbf{S} \mathbf{x}_{(-)}{ }^{-} \mathbf{T e r}_{(+)}$(II); 4. oblika je bila fonološko nenaglašena in posledično imela naglasni tip II (II/1, II/2), če so bili vsi morfemi naglasno recesivni: pbsl. $* \mathbf{R} \mathbf{x}_{(-)}-\mathbf{S} \mathbf{x}_{(-)}-\mathbf{T e r}_{(-)}$(II). ${ }^{24}$

${ }^{24} \mathrm{Tu}$ so obravnavane samo oblike brez predponskega obrazila, saj je princip pojavljanja naglasnega mesta pri oblikah s predponskim obrazilom isti. Oblika je imela naglasno mesto na predponskem obrazilu, če je bil predponski morfem naglasno dominanten, pri čemer so bili vsi sledeči morfemi lahko naglasno dominantni ali naglasno recesivni: pbsl. *'P $\mathbf{x}_{(+)}-\mathbf{R x}-\mathbf{S x}-\mathbf{T e r}\left(\mathbf{I}_{\mathbf{P x}}\right)$ (sln. pátoka 'slabo pivo, vino, žonta', nštok. pätoka, rus. па́тока, с̌еš. patoky pl. < psl. *pätoka; sln. páberək 'preostali sadež po trgatvi ali žetvi', češ. paběrek< psl. *päběrъkъ; sln. pástorka, nštok. pästōrka< psl. *pästorıka kažejo na to, da je bilo priponsko obrazilo psl. *pä- naglasno dominantno; podobno tudi psl.*prä-) (Bezlaj 1995: 15, 1, 13-14; Snoj 2003: 485). 


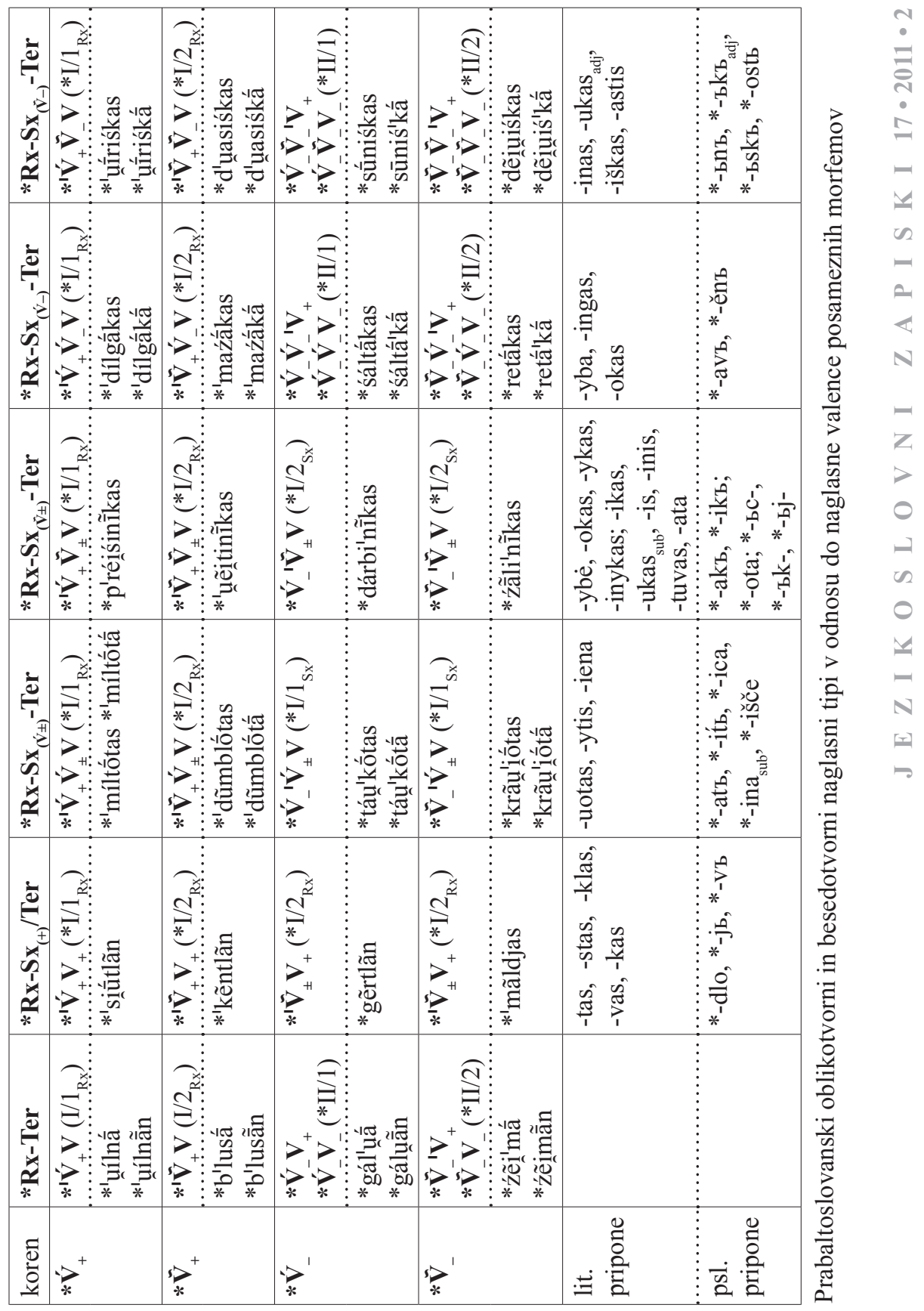


4 Od prabaltoslovanskega do praslovanskega naglasnega sistema

Primerjava praslovanskega naglasnega sistema s prabaltoslovanskim pokaže, da se praslovanski naglasni sistem od prabaltoslovanskega razlikuje po nekaterih slovanskih naglasnih inovacijah. V praslovanščini je namreč prišlo do naglasnomestnih in tonemskih sprememb.

\subsection{Praslovanski naglasni umik po Hirtovem zakonu}

Gre za Illič-Svityčevo dopolnitev Hirtovega zakona za slovanščino: Prabaltoslovansko naglasno mesto se je v praslovanščini s prabaltoslovanskega končnega zložnika (znotraj prabaltoslovanskega naglasnega tipa II) umaknilo na prednaglasno dolžino laringalnega nastanka (Illič-Svityč 1963: 78-82; Dybo 2000: 59-64) (psl. *grÿzti, *žérti (c/a)< *gryzti, *žerti (c) = *nesti, *tręsti (c) < pbsl. *grūźtéi, *gér'téi (II/1) : *neśtéi, *trẽms'téi (II/2) (> lit. gráužti, let. graûzt 'glodati, gristi'; lit. gérti, let. dzêrt 'piti'); psl. *nožǐca, *bordavïca $\left(\mathrm{F}_{2}\right)<*$ nožicà, *bordavicá $(\mathrm{C})<$ pbsl.

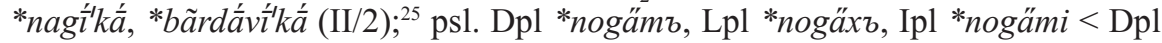
*nogambi, Lpl *nogaxb̉, Ipl *nogami = lit. Dpl nagóms, Lpl nagosè, Ipl nagomìs < pbsl. Dpl *nagấ'mus, Lpl *nagấ'su, Ipl *nagấ'mî́s). Posledica praslovanskega naglasnega umika po Hirtovem zakonu je nastanek praslovanskih naglasnih tipov c/a oziroma $\mathrm{F}_{2}$ iz dela praslovanskih naglasnih tipov c (iz prabaltoslovanskega naglasnega tipa II/1) oziroma C (in prabaltoslovanskega naglasnega tipa II z akutiranim recesivnim priponskim obrazilom $\mathrm{v}$ predzadnjem zlogu ${ }^{26}$ ter nastanek oblik s praslovanskim starim akutom na predzadnjem zlogu znotraj praslovanskega naglasnega tipa $\mathrm{c} / \mathrm{C}$.

\subsection{Praslovanski naglasni pomik po Dybojevem zakonu}

Prabaltoslovansko naglasno mesto se je v praslovanščini s prabaltoslovanskega cirkumflektiranega ali kratkega fonološko naglašenega zloga (znotraj prabaltoslo-

${ }^{25}$ Naglasni tip psl. *nožíca *nožlıco, *bordavïca *bordavïco $\left(\mathrm{F}_{2}\right)$ naj bi torej nastal iz starejšega psl. *nožicá *nöžicQ, *bordavicá *bôrdavicQ (C) po umiku naglasa po Hirtovem zakonu v oblikah z naglašeno enozložno končnico in posledično po izravnavi naglasnega mesta fonološko nenaglašenih oblik po umičnonaglašenih oblikah. Naglas prvotnih praslovanskih fonološko nenaglašenih oblik se najverjetneje posredno odraža na primer v sln. Nộžice, Stộžice, kar je rezultat izravnave naglasa po oblikah s predlogom sln. v Nộzice, v Stộzice < *vŭ Nožicę, *vb̆ Stožice (Snoj 2009: 285). Proti tezi o prvotnem praslovanskem naglasnem tipu C ( $<$ II) pri tovrstnih samostalnikih bi kazal naglas izpeljank tipa sln. goríčica, lisíčica $\leftarrow$ sln. goríca, lisíca $<$ psl. *gorï̌cica, *lisïčica $\leftarrow{ }^{*}$ gorïca, *lisíca. Naglas tipa *gorïćica *goríčico (F), *lisïčica *lisïčico (F) je torej enak naglasu tipa psl. *męsätica *męsätico $\left(\mathrm{F}<\mathrm{I} / 1_{\mathrm{Sx}}\right)$.

${ }^{26}$ Naglas izpeljanke tipa psl. *bordavicca *bordavïco $(\mathrm{F}) \leq *$ bordavicà *bôrdavice (II/2) $\leftarrow$ *bôrdavz *bordavá *bôrdavo $(\mathrm{C}=\mathrm{II} / 2) \leftarrow$ *bordá *bôrdo $(\mathrm{c}=\mathrm{II} / 2)$ kaže na prabaltoslovansko recesivno akutirano priponsko obrazilo psl. *-avz (prabaltoslovanski akut je raz-

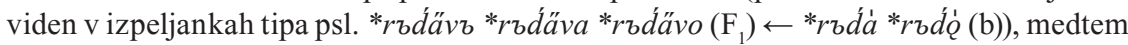

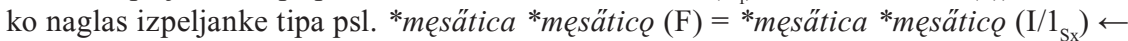
*męsätr *męsäta *męsäto $\left(\mathrm{F}_{2}=\mathrm{I} / 1_{\mathrm{Sx}}\right) \leftarrow{ }^{*}$ męso $(\mathrm{c}=\mathrm{II} / 2)$ kaže na prabaltoslovansko dominantno akutirano priponsko obrazilo psl. *-atb. 
vanskega naglasnega tipa I/2) pomaknilo na sledeči zlog (Dybo 1958; Illič-Svityč 1963) (psl. *blbxá *blbxó (b), *stolbcb *stolbca (D), *dobróta *dobróto (E), *ženíca *ženïco $\left(\mathrm{F}_{1}\right)$, *końáŕ *końára $(\mathrm{G})$; *zobbci *zobbcá $(\mathrm{B})$, *lépotá *lěpotó (B), *męsaŕb *męsaŕá (B) < starejše psl. *blüxa *blüxo, *stölbcb *stölbca, *döbrota *döbroto, *žënica *žěnicQ, *könaŕb *könára $\left(\mathrm{I} / 2_{\mathrm{Rx}}\right)$; *zobücb *zobüca, *lěpöta *lěpöto, *męsârb *męsấra $\left.\left(\mathrm{I} / 2_{\mathrm{Sx}}\right)\right)$. Posledica praslovanskega naglasnega pomika po Dybojevem zakonu je nastanek praslovanskih naglasnih tipov b, D, E, F , G (odvisno od samoglasnika, na katerega se je naglas pomaknil) iz prabaltoslovanskega naglasnega tipa $\mathrm{I} / 2_{\mathrm{Rx}}$ ter praslovanskega naglasnega tipa $\mathrm{B}$ iz prabaltoslovanskega naglasnega tipa $\mathrm{I} / 2_{\mathrm{Sx}}$. Do izostanka naglasnega pomika po Dybojevem zakonu v obliki imenovalnika-tožilnika ednine je prišlo pri praindoevropskih samostalnikih moške $o$-jevske sklanjatve, posledica česar je nastanek praslovanskega naglasnega tipa d, t. i. Illič-Svityčev arhaizem (Illič-Svityč 1963: 118-119) (pbsl. *'źãmbas *'źámba $\left.>*_{z} \hat{b} b *_{z} *_{a} a \dot{(d)}\right)$, praslovanski samostalniki $o$-jevske sklanjatve moškega spola naglasnega tipa $\mathrm{b}$ pa so nastali iz praindoevropskih baritornirah samostalnikov $o$-jevske sklanjatve srednjega spola s praindoevropsko kračino v korenu (prim. 5.5.1). ${ }^{27}$

\subsection{Praslovanska nevtralizacija tonemskih nasprotij v fonološko nenaglašenih oblikah}

Prabaltoslovanski akut in cirkumfleks v prabaltoslovanskih fonološko nenaglašenih oblikah (znotraj prabaltoslovanskega naglasnega tipa II) sta se v praslovanščini nevtralizirala v cirkumfleks, kar torej pomeni, da je poznopraslovanski stari cirkumfleks posledica tonemske nevtralizacije (psl. *gôlvQ, *nâ golvo (c); *zîmo, *nâ zimo (c); *grŷzo, *në gryzo, *ötgryzo (c); *nëso, *në neso, *ötneso (c) < pbsl.

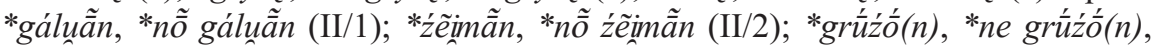
*atgrúżzóo(n) (II/1); *neśố(n), *ne neśố(n), *atneśóo(n) (II/2)). To je prvotno t. i. Meilletov zakon. ${ }^{28}$ Posledica nevtralizacije prabaltoslovanskega akuta in cirkumfleksa v fonološko nenaglašenih oblikah je sovpad prabaltoslovanskih naglasnih tipov II/1 in II/2 v praslovanski naglasni tip c/C. Tako je torej nastal praslovanski avtomatični naglas (prim. 1.1.3).

\subsection{Poznopraslovanski naglasni umik s polglasnika v šibkem položaju}

S praslovanskega polglasnika v šibkem položaju se je naglas umaknil na prednaglasni zlog, na katerem je nastal poznopraslovanski novi akut (na dolžini oziroma

${ }^{27}$ Po letu 1990 moskovska naglasoslovna šola naglasni pomik po Dybojevem zakonu pojmuje nekoliko drugače: praslovanski naglas se je s prabaltoslovanskega cirkumflektiranega ali kratkega fonološko naglašenega zloga pomaknil na sledeči dominantni akut (Dybo 2000: 93-96). Oblike tipa rus. Dpl жёнам, Lpl жёнах, Ipl жёнами so bile do leta 1990 razlagane kot inovacije znotraj ruščine (za prvotno psl. *ženämı, *ženäxъ, *ženämi), po letu 1990 pa kot prvotne (naglasnomestna premena psl. *žená : *žènams, *žénaxъ, *žènami naj bi kazala na prisotnost/odsotnost dominantnega morfema $\mathrm{v}$ drugem zlogu).

${ }^{28}$ To naglasno spremembo je prvi formuliral A. Meillet (1902), ki je govoril o metatoniji akut $>$ cirkumfleks. Razlika med Meilletovim in Dybojevim pojmovanjem naglasne spremembe je v tem, da Meillet metatonijo pojmuje kot spremembo naglasa v zlogu, ki je naglašen, medtem ko Dybo govori o nevtralizaciji tonema v zlogu, ki ni naglašen. 
na kračini odvisno od kolikosti prednaglasnega zložnika) (Ivšić 1911: 182-194)

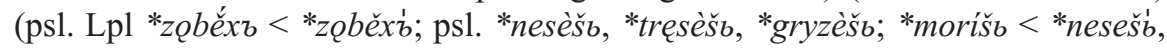
*tręsešb, *gryzešb; *morišb).

\subsection{Poznopraslovanski naglasni umik z nestaroakutiranega srednjega zloga}

$\mathrm{S}$ praslovanskega kratkega ali dolgega srednjega besednega zloga $\mathrm{v}$ okviru praslovanskega naglasnega tipa $b$, tj. s praslovanskega kratkega/dolgega samoglasnika $z$ naglasom tipa novega akuta (s praslovanskega kratkega ali dolgega starocirkumflektiranega samoglasnika po starejši formulaciji), je v pozni praslovanščini prišlo do naglasnega umika na prednaglasni zlog, na katerem je nastal poznopraslovanski novi akut (na dolžini oziroma na kračini odvisno od kolikosti prednaglasnega zložnika) (Ivšić 1911: 169-177; Stang 1957: 169-170). To je t. i. Ivšić-Stangov zakon. Do naglasnega umika ni prišlo v vseh oblikotvornih in besedotvornih vzorcih ter v vseh naglasnih tipih (psl. *mòžete, *nòsite, *blódite $<*$ možète, *nosite, *blodite: *dobròta, *modróstb).

Tako se na primer pri praslovanskih glagolih na $*_{-i-t i} *_{-i-s ̌ b}$ pojavljata dva podtipa naglasnega tipa $b\left(b_{1}, b_{2}\right)$ glede na besedotvorni pomen (iterativi, kavzativi, denominativi): a) iterativi, tj. ponavljalni glagoli, izkazujejo splošnoslovanski umik naglasa s praslovanskega dolgega srednjega zložnika z naglasom tipa novega akuta (psl. *blódišb *blódite < *blodišb *blodite $\left(\mathrm{b}_{1}\right)$, *nòsišs *nòsite $<$ *nosišs *nosite $\left(\mathrm{b}_{1}\right)$; b) kavzativi in denominativi (desubstantivi, deadjektivi), tj. vzročni in (izsamostalniški, izpridevniški) izimenski glagoli, pa umika naglasa s praslovanskega dolgega srednjega zložnika z naglasom tipa novega akuta v vseh slovanskih jezikih ne izkazujejo (psl. *xvališb *xvalite $\left(\mathrm{b}_{2}\right)$, *ložlšs $*$ ložite $\left.\left(\mathrm{b}_{2}\right)\right)$. Tako se na slovanskem jezikovnem ozemlju glede na prisotnost : odsotnost naglasnega umika $\mathrm{s}$ praslovanskega dolgega srednjega samoglasnika $\mathrm{z}$ naglasom tipa novega akuta $\mathrm{v}$ okviru praslovanskega naglasnega tipa $b_{2}$ na prednaglasno dolžino (psl. *xvališs *xvalite > nespl. sl. *xválišb *xválite) oziroma na prednaglasno kračino (psl. *ložišs *ložite > nespl. sl. *ložišs *ložite) pojavljajo štirje osnovni naglasni sistemi (Dybo -Zamjatina - Nikolajev 1990: 109-129): 1. tip *xválišb, *ložišb (severna slovenščina, kajkavščina, severna čakavščina); 2. *xvališs, *ložišb (štokavščina); 3. *xválišb *ložišb (južna slovenščina, južna čakavščina, knjižna beloruščina); 4. *xvališs *ložišs (knjižna ruščina). ${ }^{29}$

\begin{tabular}{|l|l|l|l|}
\hline $\begin{array}{l}\text { *xvališs *xvalite } \\
\text { *ložišb *ložite }\end{array}$ & $\begin{array}{l}\text { *xválišb *xválite } \\
\text { *ložišb *ložite }\end{array}$ & $\begin{array}{l}\text { *xvališs *xvalite } \\
\text { *lòžišb *lòžite }\end{array}$ & $\begin{array}{l}\text { *xválišb *xválite } \\
\text { *lòžišb *lòžite }\end{array}$ \\
\hline
\end{tabular}

Slovanski naglasni sistemi glede na umika naglasa s srednjega zloga (razvrščeni od leve proti desni od najbolj arhaičnega do najbolj inovativnega)

${ }^{29}$ Slovensko jezikovno ozemlje se na osnovi nesplošnoslovanskih naglasnih razlik deli na dva areala s temile nesplošnoslovanskimi pojavi: 1. severnoslovenski naglasni tip (psl.

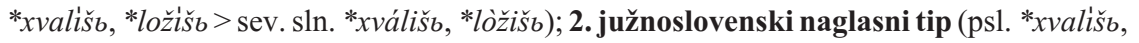
*ložišs > juž. sln. *xválišb, *ložišb). Natančna meja med naglasnima makroarealoma še ni natančno določena. K severnoslovenskemu naglasnemu tipu naj bi spadala štajerska narečja, rezijansko narečje in morda koroška narečja. 
Prabaltoslovanska izhodišča praslovanskih naglasnih tipov so torej tale: psl. a, A $<$ pbsl. I/1 $1_{\mathrm{Rx}}$; psl. b, D, E, $\mathrm{F}_{1}, \mathrm{G}<$ pbsl. I/2 ${ }_{\mathrm{Rx}}$; psl. B $<$ pbsl. I/2 $2_{\mathrm{Sx}}$; psl. $\mathrm{F}_{2}<$ pbsl. $\mathrm{I} / 1_{\mathrm{Sx}} ;$ psl. c $/ \mathrm{a}<$ pbsl. II/1; psl. c, C $<$ pbsl. II/1, II/2.

Besedotvorni predhodniki

\begin{tabular}{|c|c|c|c|c|}
\hline naglasni tip & $* \mathbf{I} / \mathbf{1}>* \mathbf{a}$ & $* \mathbf{I} / \mathbf{2}>*^{*} \mathbf{b}$ & $* I I / 1>* c(/ a)$ & $* I I / 2>* c$ \\
\hline $\begin{array}{l}\text { samostalnik, } \\
\text { pridevnik }\end{array}$ & $\begin{array}{l}\text { *vb̈lna } \\
\text { *v"̈lne }\end{array}$ & $\begin{array}{l}\text { *žëna } \\
\text { *žëno }\end{array}$ & $\begin{array}{l}\text { *golvà } \\
*_{\text {gölvo }}\end{array}$ & $\begin{array}{l}\text { *bordà } \\
\text { *bôrde }\end{array}$ \\
\hline glagol & $\begin{array}{l}\text { *lê̌sti } \\
\text { *lĕ̌zQ } \\
\text { *lê̌zešı } \\
\text { *lĕ̌zete }\end{array}$ & $\begin{array}{l}\text { *mögti } \\
\text { *mögQ } \\
\text { *möžešs } \\
\text { *möžete }\end{array}$ & $\begin{array}{l}\text { * gryzti } \\
\text { * gry̌zQ } \\
\text { *gryzeš́ } \\
\text { * gryzeté }\end{array}$ & $\begin{array}{l}\text { *tręstí } \\
\text { *tręse } \\
\text { *tręsešs } \\
\text { *tręseté }\end{array}$ \\
\hline
\end{tabular}

Izpeljanke $\mathrm{z}$ naglasno dominantnimi priponskimi obrazili

\begin{tabular}{|c|c|c|c|c|}
\hline${ }^{*} \mathbf{R x}-\mathbf{S} x_{(\dot{V} \pm)}-$ Ter & 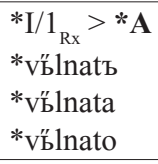 & $\begin{array}{l}{ }^{*} \mathrm{I} / 2_{\mathrm{Rx}}>* \mathbf{F}_{1} \\
\text { *žènaţ } \\
\text { *žënata } \\
\text { *žënato }\end{array}$ & $\begin{array}{l}* \text { I/ } 1_{\text {Sx }}>* \mathbf{F}_{2} \\
* \text { golva̋tb } \\
* \text { golva̋ta } \\
\text { * golva̋to }\end{array}$ & $\begin{array}{l}* \mathrm{I} / 1_{\mathrm{Sx}}>{ }^{*} \mathbf{F}_{2} \\
* \text { borda̋tb } \\
* \text { borda̋ta } \\
* \text { borda̋to }\end{array}$ \\
\hline${ }^{*} \mathbf{R x}-\mathbf{S} x_{(\overline{\mathbf{V}} \pm)}-$ Ter & $\begin{array}{l}\text { *I/1 } 1_{\mathrm{Rx}}>* \mathbf{A} \\
\text { *körvaŕ } \\
\text { *körvaŕa }\end{array}$ & $\begin{array}{l}\text { *I/2 } 2_{\mathrm{Rx}}>\text { *G } \\
\text { *köńá́ } \\
\text { *köńá́a }\end{array}$ & $\begin{array}{l}\text { *I/2 }>\text { Sx } \\
\text { *męsâŕ́ } \\
\text { *męsâŕa }\end{array}$ & $\begin{array}{l}* \mathrm{I} / 2_{\mathrm{Sx}}>* \mathbf{B} \\
* \text { petấr } \\
* \text { petấra }\end{array}$ \\
\hline \multirow[t]{2}{*}{$* \mathbf{R x}-\mathbf{S} \mathbf{x}_{(\check{V} \pm)}-\mathbf{T e r}$} & $\begin{array}{l}* \mathrm{I} / 1_{\mathrm{Rx}}>* \mathbf{A} \\
* \text { čístota } \\
* \text { čístoto }\end{array}$ & $\begin{array}{l}* \mathrm{I} / 2_{\mathrm{Rx}}>* \mathbf{E} \\
* \text { döbrota } \\
* \text { döbroto }\end{array}$ & $\begin{array}{l}* \mathrm{I} / 2_{\mathrm{Sx}}>* \mathbf{B} \\
\text { *živöta } \\
\text { *živötQ }\end{array}$ & $\begin{array}{l}* \mathrm{I} / 2_{\mathrm{Sx}}>* \mathbf{B} \\
* \text { lěpöta } \\
\text { *lěpöto }\end{array}$ \\
\hline & $\begin{array}{l}* \mathrm{I} / 1_{\mathrm{Rx}}>* \mathbf{A} \\
\text { * stärbcb } \\
\text { *stärbca }\end{array}$ & $\begin{array}{l}* \mathrm{I} / 2_{\mathrm{Rx}}>* \mathbf{D} \\
*_{\text {stölbcb }} \\
*_{\text {stölbca }}\end{array}$ & $\begin{array}{l}* \mathrm{I} / 2_{\mathrm{Sx}}>* \mathbf{B} \\
* \text { tučb̆cb } \\
* \text { tučšca }\end{array}$ & $\begin{array}{l}* \mathrm{I} / 2_{\mathrm{Sx}}>* \mathbf{B} \\
*_{\text {zQbb̈cb }} \\
*_{\text {zQbb̆ca }}\end{array}$ \\
\hline
\end{tabular}

Izpeljanke z naglasno recesivnimi priponskimi obrazili

\begin{tabular}{|c|c|c|c|c|}
\hline$* \mathbf{R x}-\mathbf{S} \mathbf{x}_{(\dot{v}-)}-$ Ter & $\begin{array}{l}* \mathrm{I} / 1_{\mathrm{Rx}}>*^{*} \mathrm{~A} \\
* \text { koorstavb } \\
\text { *körstava } \\
\text { *kőrstavo }\end{array}$ & $\begin{array}{l}* \mathrm{I} / 2_{\mathrm{Rx}}>* \mathbf{F}_{1} \\
\text { *rb̆d́avb } \\
\text { *rb̆d́ava } \\
\text { *rb̆d́avo }\end{array}$ & $* \mathrm{II} / 1>{ }^{*} \mathbf{C}$ & $\begin{array}{l}* \mathrm{II} / 2>\text { *C } \\
\text { *krb̌vavъ } \\
\text { *krъvavá } \\
\text { *krb̌vavo }\end{array}$ \\
\hline${ }^{*} \mathbf{R x}-\mathbf{S} \mathbf{x}_{(\bar{V}-)}-$ Ter & $\begin{array}{l}* \mathrm{I} / 1_{\mathrm{Rx}}>* \mathbf{A} \\
-\end{array}$ & $\begin{array}{l}* \mathrm{I} / 2_{\mathrm{Rx}}>* \mathbf{G} \\
-\end{array}$ & ${ }_{-}^{*} \mathrm{II} / 1>* \mathbf{C}$ & $\begin{array}{l}* \mathrm{II} / 2>* \mathrm{C} \\
-\end{array}$ \\
\hline \multirow[t]{2}{*}{${ }^{*} \mathbf{R x}-\mathbf{S} x_{(\check{V}-)}-$ Ter } & $\begin{array}{l}* \mathrm{I} / 1_{\mathrm{Rx}}>* \mathbf{A} \\
\text { *stärostb } \\
\text { *stärosti }\end{array}$ & $\begin{array}{l}* \mathrm{I} / 1_{\mathrm{Rx}}>{ }^{*} \mathbf{E} \\
\text { *môdrostb } \\
\text { *mồdrosti }\end{array}$ & 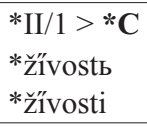 & $\begin{array}{l}{ }^{*} \mathrm{II} / 2>{ }^{*} \mathrm{C} \\
{ }^{*} \text { môldostь } \\
{ }^{*} \text { môldosti }\end{array}$ \\
\hline & 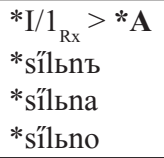 & $\begin{array}{l}* \mathrm{I} / 1_{\mathrm{Rx}}>\text { *D } \\
\text { * grěšbnb } \\
\text { * grěšsna } \\
\text { * grěšsno }\end{array}$ & $\begin{array}{l}\text { *II/1 > *C } \\
\text { *tüččnъ } \\
\text { *tučsná } \\
\text { *tǔčsno }\end{array}$ & $\begin{array}{l}\text { *II/2> *C } \\
\text { *möt́́tınъ } \\
\text { *mot́t́ná } \\
\text { *möt́tsno }\end{array}$ \\
\hline
\end{tabular}

Zgodnjepraslovanski oblikotvorni in besedotvorni naglasni tipi 
- 5 Od praindoevropskega do prabaltoslovanskega naglasnega sistema

Prabaltoslovanski naglasni sistem se je izoblikoval iz praindoevropskega po specifičnih prabaltoslovanskih inovacijah, ki zajemajo tako regularne naglasne spremembe (prabaltoslovanski naglasni umik po Hirtovem zakonu, nastanek prabaltoslovanskih tonemskih nasprotij v neizglasnih zlogih, prabaltoslovanska metatonija) kot tudi analogne modifikacije naglasnih sprememb (nastanek prabaltoslovanskega mobilnega naglasnega tipa). ${ }^{30}$

\subsection{Prabaltoslovanski naglasni umik po Hirtovem zakonu (z Illič-Svityčevo dopolnitvijo)}

Praindoevropski naglas se je v prabaltoslovanščini z indoevropskega končnega zložnika nelaringalnega nastanka umaknil na indoevropski prednaglasni dolgi zložnik laringalnega nastanka (Hirt 1895: 58; Illič-Svityč 1963: 72-83): ${ }^{31}$ psl. *dÿmъ

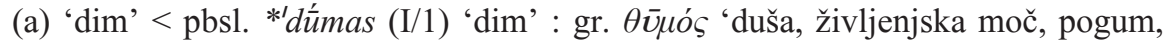
strast', sti. dhūmáh 'dim, sopara' < pie. *dh $u \boldsymbol{h}_{2}$ mós 'dim'; psl. *grîva (a) 'griva'

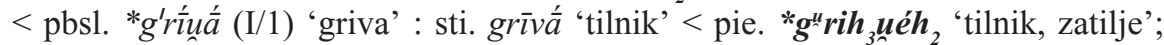
pblt. *'dóná̀ (I/1) 'kruh' : sti. dhānáh pl. 'žito’ < pie. *deh néh 'kar je dano'; psl. *pülnъ *pülna *pülno (a) 'poln' < pbsl. *'pílnas *'pílná *ílnán (I/1) 'poln' : sti.

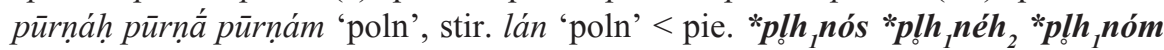
'napolnjen'. Posledica prabaltoslovanskega naglasnega umika po Hirtovem zakonu je nastanek prabaltoslovanskih samostalnikov z nemobilnim naglasnim tipom iz dela praindoevropskih oksitoniranih samostalnikov.

V primerih tipa pbsl. *g'ríñ ga umika po zgoraj formuliranem naglasnem pravilu ne bi pričakovali. Prav tako imajo proti pričakovanju nekateri indoevropski oksitonirani samostalniki s prednaglasno dolžino laringalnega nastanka v prabaltoslovanščini mobilni naglasni tip

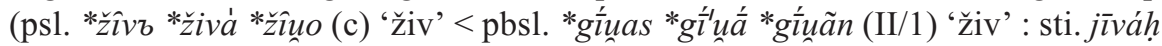

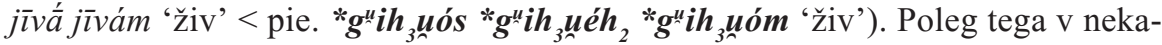
terih primerih vsa baltoslovanščina ne izkazuje istega stanja (psl. *síto (a) 'sito', lit. sietas (1) 'sito' < nespl. pbsl. *'séitãn : let. siêts 'sito; bedro, stegno' < nespl. pbsl. *séítãn $\leftarrow$ pie. *sēîtóm 'sito'). ${ }^{32}$ Navedena odstopanja od pričakovanega

${ }^{30} \mathrm{~V}$ nadaljevanju so prabaltoslovanske fonološko nenaglašene oblike podane brez ikta, znaka za naglasno mesto. Fonetično naglasno mesto se nahaja na prvem zlogu fonetične besede.

${ }^{31}$ Hirt je zakon prvič podal $\mathrm{v}$ referatu Über den Akzent der $i$ - und $u$-Deklination im Indogermanischen v Indoevropeistični sekciji Filološkega seminarja na Dunaju leta 1893 (Streitberg 1894: 164), prvič pa ga objavil v svoji naglasoslovni monografiji leta 1895. Hirtov zakon je leta 1963 dopolnil Illič-Svityč, natančneje je določil naravo zložnika, s katerega se naglas umakne.

${ }^{32}$ Trimorni dvoglasnik v *seititóm ni nastal neposredno iz *seh itóm (ker bi se to spremenilo $*_{s e h}$ itóm $>*_{\text {seitóm), temveč je bil posplošen iz sedanjiške osnove pie. } *^{*} \text { seh }_{l}-\text { ie- }}$ (> psl.

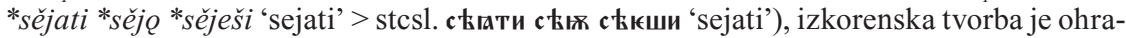
njena v stčeš. sieto < psl. *sě̃to 'sito' < nespl. pbsl. *sētán < pie. *seh tóm (Metka Furlan v Bezlaj 1995: 239). 
stanja so najverjetneje posledica analognih izravnav. Znotraj tistih pregibalnih vzorcev namreč, v katerih sta se v indoevropščini v končnem zlogu izmenjevali kračina ali dolžina kontrakcijskega nastanka na eni ter laringalna dolžina na drugi strani, so se v zgodnji prabaltoslovanščini izmenjevale oblike z naglasom na predzadnjem zlogu na eni ter oblike z naglasom na zadnjem zlogu na drugi

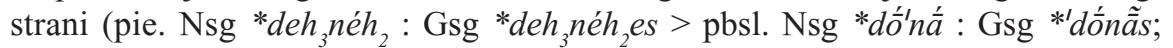

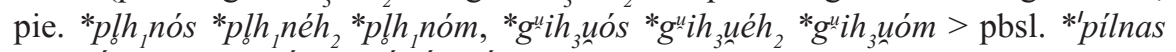

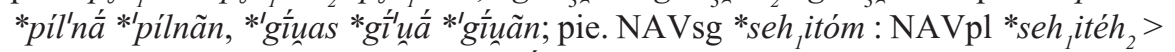
pbsl. NAVsg *'séitãn : NAVpl *séiltá). Pozneje je prišlo do izravnave naglasa ene od oblik, večinoma že v prabaltoslovanščini, čeprav ne v vseh primerih. ${ }^{33}$

\subsection{Oblikovanje prabaltoslovanske naglasne valence morfemov}

$\mathrm{Na}$ osnovi praindoevropske naglašenosti oziroma nenaglašenosti posameznih morfemov je v prabaltoslovanščini prišlo do izoblikovanja naglasne valence morfemov. Praindoevropski naglašeni morfemi so v prabaltoslovanščini naglasno dominantni morfemi (+), tj. inherentno fonološko naglašeni. Prabaltoslovanski naglasno dominantni morfemi so bili korenski (indoevropski naglašeni koreni, tj. koreni indoevropskih bariton; prim. 5.5.1), priponski (indoevropska naglašena priponska obrazila; prim. 3.2.2), končniški (prim. 3.2.3).

Praindoevropski nenaglašeni morfemi so v baltoslovanščini naglasno recesivni morfemi (-), tj. inherentno fonološko nenaglašeni. Prabaltoslovanski naglasno recesivni morfemi so korenski (indoevropski nenaglašeni koreni, tj. koreni indoevropskih oksiton; prim. 5.5.2), priponski (indoevropska nenaglašena priponska obrazila; prim. 3.2.2), končniški (prim. 3.2.3).

\subsection{Nastanek prabaltoslovanskih tonemskih nasprotij $v$ neizglasnih zlogih (prvi de Saussurjev zakon ali zakon stóti)}

Baltščina, grščina in germanščina v izglasnih zlogih pogosto izkazujejo vzporednice v vrsti tonema (ali v njegovem kolikostno-kakovostnem odrazu zložnika), kar je najverjetneje skupna poznopraindoevropska inovacija ali vsaj tendenca (Hanssen

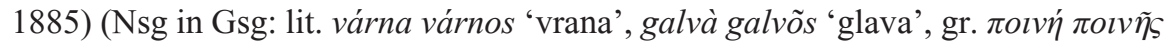

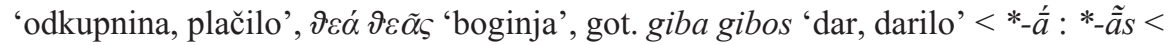

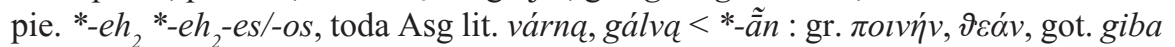
$<*$-àn $<$ pie. $*_{-}$eh, $\left.m\right)$.

Za razliko od tonemskih nasprotij $\mathrm{v}$ izglasnih zlogih pa so tonemska nasprotja v nezadnjih zlogih prabaltoslovanska inovacija. Indoevropska kolikostna naprotja dolžina : kračina so se namreč v prabaltoslovanščini spremenila $\mathrm{v}$ tonemska nasprotja akut : cirkumfleks (Bezzenberger 1877; Fortunatov 1880; de Saussure 1894): A) indoevropski »dolgi« zložniki imajo v prabaltoslovanščini akut (rastoči tonem), in sicer: a) praindoevropski kratki zložniki v položaju pred laringalom in

${ }^{33}$ Slovanski in baltski jezki se $\mathrm{v}$ načinu izravnave naglasa $\mathrm{v}$ večini primerov ujemajo (lit. dúona dúonos $(1)=$ let. duõna duõnas, psl. *pölnъ *pölna $(\mathrm{a})=$ stlit. pilnas pilna $(1)=$ let.

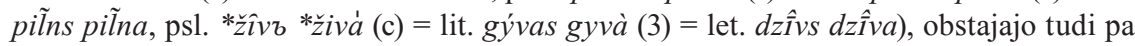
razlike med samimi vzhodnobaltskimi jeziki $($ psl. *sïto $(a)=$ lit. síetas $(1) \neq$ let. siêts $)$. 
soglasnikom; b) praindoevropski dolgi zložniki, nastali po kvantitativnem prevoju po podaljšavi (po vrddhiju); c) prabaltoslovanski dolgi samoglasniki, nastali v prabaltoslovanščini po podaljšavi praindoevropskih kratkih samoglasnikov v položaju pred neaspiriranimi nezvenečini zaporniki po Winterjevem zakonu (Winter 1978) (prim. 5.5.1 A, 5.5.2 A); B) indoevropski »kratki« zložniki, tj. praindoevropski kratki zložniki v položaju ne pred laringalom in soglasnikom, imajo v prabaltoslovanščini cirkumfleks (padajoči tonem) oziroma kračino (prim. 5.5.1 B, 5.5.2 B). ${ }^{34}$

\subsection{Prabaltoslovanska metatonija}

V prabaltoslovanščini je prišlo do besedotvorno pogojene metatonije, tj. tonemske spremembe, v smereh akut $>$ cirkumfleks (»métatonie douce «) in cirkumfleks $>$ akut (»métatonie rude«) (de Saussure 1894). Metatonija tipa cirkumfleks $>$ akut ima vzroke $\mathrm{v}$ že praindoevropščini, in sicer $\mathrm{v}$ indoevropskem kvantitativnem prevoju po podaljšavi (osnovna prevojna stopnja : vrddhijevska podaljšana prevojna stopnja) (pie. “uórnos 'vran' : pie. *ứrneh 'pripadajoča vranu'> pbsl. *'uãrnas 'vran' : *'uárnấa 'vrana' > lit. var̃nas 'vran' : várna 'vrana', psl. *vôrnъ 'vran' : *vörna 'vrana' > sln. vrân : vrána, nštok., čak. vrân : vräna, rus. ворон : воро́на) ali prabaltoslovanskem prevoju po podaljšavi praindoevropske ničte prevojne stopnje (po modelu praindoevropskega kvantitativnega prevoja po podaljšavi), medtem kot je do metatonije tipa akut > cirkumfleks prišlo v prabaltoslovanščini. V teoretičnem modelu moskovske naglasoslovne šole je šlo pri prabaltoslovanski metatoniji za spremembo naglasne valence morfema: recesivni morfem je postal dominanten, če mu je sledil dominantni morfem (dominantni morfemi so na primer besedotvorna

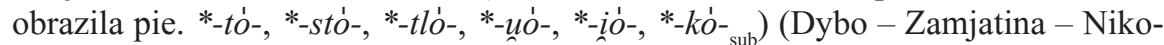
lajev 1990: 85-108).

Če prabaltoslovanskemu (akutiranemu ali cirkumflektiranemu) dominantnemu morfemu neposredno sledi dominantni morfem, ne prihaja do nikakršnih prabaltoslovanskih naglasnih sprememb: dominantni + dominantni morfem $=$ dominantni + dominantni morfem: pbsl. $* \mathbf{V}_{+} \mathbf{V}_{+}(\mathbf{I})=* \mathbf{V}_{+} \mathbf{V}_{+}$(I): a) pbsl. $* V_{+} V_{+}(I / 1)$

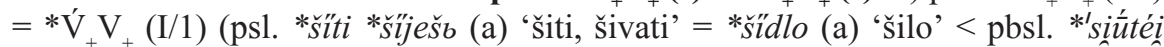

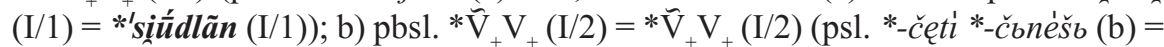
*čędló (b) < pbsl. *'kĩntéi (I/2) = *'kĩndlãn (I/2)).

Če prabaltoslovanskemu (akutiranemu ali cirkumflektiranemu) recesivnemu morfemu neposredno sledi dominantni morfem, recesivni morfem postane drugotni dominantni morfem: recesivni + dominantni morfem $>$ drugotni dominantni + dominantni morfem: pbsl. * $\mathbf{V}_{-} \mathbf{V}_{+}$(II) $>* \mathbf{V}_{ \pm} \mathbf{V}_{+}$(I): a) Če akutiranemu recesivnemu morfemu neposredno sledi dominantni morfem, akutirani recesivni morfem postane cirkumflektirani drugotni dominantni morfem, $\mathrm{tj}$. spremeni naglasno valenco (rece-

${ }^{34}$ Formulirani pravili nastanka prabaltoslovanskih tonemov veljata za večino primerov. Pojavljajo pa se tudi odstopanja oziroma celo dvojni odrazi istega izhodišča (na primer tonem končnice imenovalnika množine moške o-jevske sklanjatve pie. *oi, sicer zaimenskega izvora; v baltščini samostalniki izkazujejo cirkumfleks, medtem ko pridevniki izkazujejo akut: lit. maišaĩ 'vreče' : indef. sausì, def. sausíeji 'suhi' < pbsl.

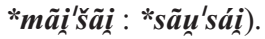


sivni morfem $>$ dominantni morfem) in doživi metatonijo (akut $>$ cirkumfleks): akutirani recesivni + dominantni morfem $>$ cirkumflektirani drugotni dominantni + dominantni morfem: pbsl. $* \mathrm{~V}^{\prime} \mathrm{V}_{+}(\mathrm{II} / 1)>* \widehat{\mathrm{V}}_{+} \mathrm{V}_{+}$(I/2) (psl. *žérti *ž́brešb (c/a) ‘žreti’ : *žerdló (b) ‘žrelo' < pbsl. *gér'téi (II/1) : *'gẽrdlãn (I/2) < *gérdlãn (II/1));

b) Če cirkumflektiranemu recesivnemu morfemu neposredno sledi dominantni morfem, cirkumflektirani recesivni morfem postane cirkumflektirani drugotni dominantni morfem, tj. spremeni naglasno valenco (recesivni morfem $>$ dominantni morfem), ne doživi pa metatonije: cirkumflektirani recesivni + dominantni morfem $>$ cirkumflektirani drugotni dominantni + dominantni morfem: pbsl. $* \widehat{\mathrm{V}} \mathrm{V}_{+}(\mathrm{II} / 2)>$ * $\widehat{\mathrm{V}}_{+} \mathrm{V}_{+}(\mathrm{I} / 2)$ (psl. *môld ъ *moldá *môldo (c) 'mlad' : *mold́b *mold́a (b) 'mlaj' < pbsl. *mãldas *mãl'dá *mãldãn (II/2) : *'mãldian (I/2) < *mãldias (II/2)).

\subsection{Nastanek prabaltoslovanskega mobilnega naglasnega tipa}

Iz praindoevropskega oksitoniranega naglasnega tipa je (z izjemo $\mathrm{v}$ primerih, $\mathrm{v}$ katerih je po delovanju Hirtovega zakona v baltoslovanščini prišlo do nastanka baritoniranega naglasnega tipa) nastal prabaltoslovanski mobilni naglasni tip, najverjetneje po vzoru praindoevropskega amfikinetičnega mobilnega naglasno-prevojnega tipa. Podrobnosti nastanka naglasnih značilnosti posameznih oblik znotraj mobilnega naglasnega vzorca niso povsem jasne. ${ }^{35} \mathrm{~V}$ prabaltoslovanščini se tako glede na svoji praindoevropski izhodišči izoblikujeta dva dopolnjujoče razvrščena naglasna tipa glede na fonološko naglašenost korenov (dominantnost : recesivnost), ki sta glede na tonem zložnika v osnovi imela vsak po dva naglasna podtipa.

\subsubsection{Prabaltoslovanski nemobilni naglasni tip (I)}

Prabaltoslovanski nemobilni naglasni tip (I) je nastal iz praindoevropskega baritoniranega naglasnega tipa (s fonološko naglašenim korenom) ter iz praindoevropskega oksitoniranega naglasnega tipa, ki je po delovanju Hirtovega zakona v prabaltoslovanščini prešel v baritonirani naglasni tip (fonološko nenaglašeni koren je postal fonološko naglašeni morfem), in sicer:

A) podtip z akutiranim zložnikom v korenu (I/1): a) iz praindoevropskega baritoniranega naglasnega tipa $\mathrm{z}$ indoevropsko dolžino laringalnega nastanka (psl. *vólna (a) 'volna'< pbsl. *'uílná (I/1) 'volna', sti. úrnāa < *ứrnā 'volna', lat. lāna

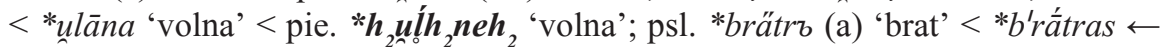
pbsl. *b'rắtẽ r (I/1) 'brat', sti. bhrắtā 'brat', gr. $\varphi \rho \tilde{\alpha} \tau \eta \rho$ 'član istega rodu, plemena, družine', got. brōpar 'brat' < pie. *'b'réh tēer 'brat'; psl. *tÿlı (a) 'tilnik', sti. tùlam 'šop, čop' < pie. 'túh $\boldsymbol{h}_{2}$ lom); b) iz praindoevropskega baritoniranega naglasnega tipa z indoevropsko dolžino prevojnega nastanka (psl. *lípa (a) 'lipa'< pbsl. *'léipa (I/1) 'lipa' < pie. *lếipeh 'lepljiva'); c) iz praindoevropskega oksitoniranega naglasnega tipa po delovanju Hirtovega zakona (tudi $\mathrm{v}$ tistih primerih, kjer je $\mathrm{v}$ naglasnih vzorcih $\mathrm{z}$ oblikami $\mathrm{z}$ regularno umanjkanim naglasnim umikom pozneje po analogiji prišlo do posplošitve naglasnega mesta na kore-

${ }^{35} \mathrm{~V}$ primerjavi z drugimi naglasoslovnimi modeli geneze prabaltoslovanskega naglasnega sistema Dybojev in Illič-Svityčev model nastanka naglasa $\mathrm{v}$ posameznih oblikah pregibalnih vzorcev ne pojasnjuje. 
nu) (pbsl. *'dúmas (I/1) 'dim'< pie. *d'uh $\boldsymbol{h}_{2}$ mós; pbsl. *g'rî́ná (I/1) 'griva' $\leq$ pie.

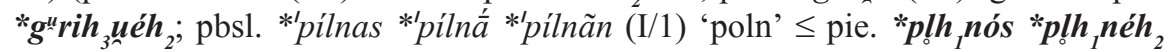
*plh ${ }_{1}$ nóm);

B) podtip s cirkumflektiranim ali kratkim zložnikom v korenu (I/2) iz praindoevropskega baritoniranega naglasnega tipa s praindoevropsko kračino v korenu

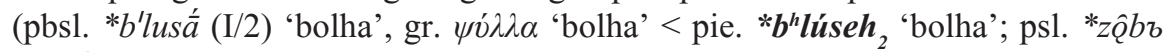

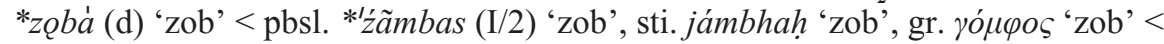
pie. "'góm $\boldsymbol{b}^{h} \boldsymbol{\text { os }}$ 'zob'; psl. *pod' *podá (b) 'pod, tla'< pbsl. *'padas (I/2) 'pod, tla', gr. $\pi \delta ́ \delta o v ~ ' t l a '<$ pie. *pódom, *pédom; ${ }^{36}$ pbsl. *'aśtras *'aśtráa *'aśtrãn (I/2) 'oster',

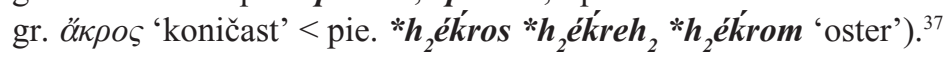

\subsubsection{Prabaltoslovanski mobilni naglasni tip (II)}

Prabaltoslovanski mobilni naglasni tip (II) je nastal iz praindoevropskega oksitoniranega naglasnega tipa (s fonološko nenaglašenim korenom), in sicer:

A) podtip z akutiranim zložnikom v korenu (II/1): a) v korenih s praindoevropsko prevojno dolžino (psl. *golvà *gôlvo (c) 'glava' < pbsl. *gál'uáa *gáluãa (II/1) 'glava' < pie. *ghōluéh ; psl. *smôrdz (c) 'smrad' < pbsl. *smárdas (II/1) 'vonj, smrad'< pie. *smōrdós; psl. *mệso (c) 'meso'< pbsl. *mémsãn (II/1) 'meso', sti. māmsám 'meso', got. mimz 'meso' < pgerm. *mimzán < pie. *mēmsóm 'meso'); b) v korenih s prabaltoslovansko dolžino, nastalo po Winterjevem zakonu (psl. *nâgъ *nagá *nâgo (c) 'nag' < pbsl. *nốgas *nó'gà̃ *nốgãn (II/1) 'nag' < *nōg"ós *nōguéh ${ }^{*}$ "nog góm < pie. *nog"ós *nog"éh *nog"óm 'nag'); c) v tistih primerih, ko je v naglasnih vzorcih z oblikami z regularno umaknjenim naglasom po delovanju Hirtovega zakona po analogiji prišlo do posplošitve naglasnega mesta na končnici

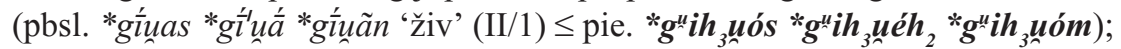

B) podtip s cirkumflektiranim ali kratkim zložnikom v korenu (II/2) v korenih s praindoevropsko kračino (psl. *cěnà *cêno (c) 'cena'< pbsl. *kãíná *kãinãan

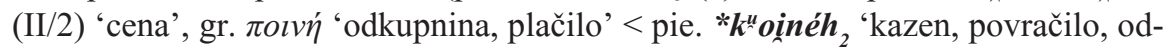

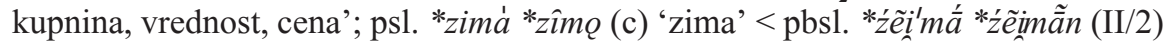

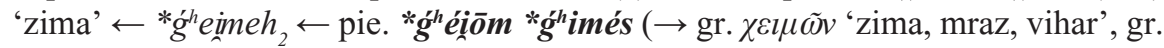

${ }^{36}$ Iz praindoevropskih baritoniranih samostalnikov $o$-jevske sklanjatve srednjega spola $\mathrm{s}$ praindoevropsko kračino v korenu so v praslovanščini nastali praslovanski samostalniki $o$-jevske sklanjatve moškega spola naglasnega tipa b (pie. *pódom $>$ psl. *podí). Do prehoda srednji spol > moški spol je prišlo zaradi glasovne spremembe pie. ${ }^{*}$-om $>$ psl. $*_{-b}$ (: pie. ${ }_{-}^{*}-m>$ psl. *-o). Pri praslovanskih samostalnikih srednjega spola z nemobilnim naglasnim tipov (pie. *léh tom $>$ psl. *lětto), pri katerih bi pričakovali enako glasovno spremembo (pie. *léh ${ }_{l}$ tom > psl. **lětr ), je prišlo do analogne posplošitve izglasnega psl. *-o, in sicer pri v praindoevropščini pogosto naglašenih priponskih obrazilih (pie. *-tó-, *-ló-, *-tló-), dokaz omahovanja pa so dvojni odrazi (pie. *túh 1893; Illič-Svityč 1963: 131-133).

${ }^{37}$ Premenjevanje prabaltoslovanskega akuta in cirkumfleksa oziroma kračine znotraj pregibalnega vzorca je posledica premenjevanja zlogovne strukture $\mathrm{v}$ praindoevropščini (prisotnosti laringala v položaju pred soglasnikom : odsotnost laringala v položaju pred samoglasnikom ali pred *in) (psl. *mélti *méléšb (b/a) $<*^{\prime}$ méltéi $*^{\prime}$ meliesei $(\mathrm{I} / 1 / \mathrm{I} / 2)<$ 
$\chi \varepsilon \tilde{u} \mu \alpha$ 'zima, mraz, vihar', sti. héman 'pozimi' < *'gheim-; lat. hiems 'nevihta, zima, mraz' < *g'hiem-); psl. *nogá *nögQ (c) 'noga'< pbsl. *na'gáa *nagã̃n (II/2) 'nohti,

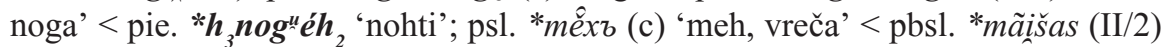
'meh, vreča', sti. meșáh 'oven' < pie. *moisós ‘oven, ovčja koža'; psl. *sûxъ *suxá *sûxo (c) 'suh' < pbsl. *sãusas *sãu's'á *sãusãn (II/2) 'suh', sti. śoșah 'izsušujoč',

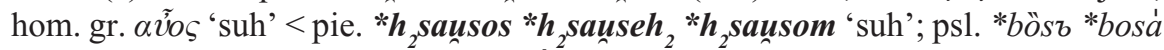
*böso (c) 'bos' < pbsl. *basas *ba'sá *basãn (II/2) 'bos', stvn. bar 'bos, nag' <

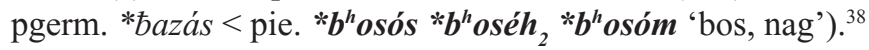

\section{Zaključek}

Relativna kronologija naglasnih pojavov od praindoevropščine preko prabaltoslovanščine do praslovanščine bi bila v luči moskovske naglasoslovne šole lahko sledeča:

(1) prabaltoslovanski naglasni umik po Hirtovem zakonu (z Illič-Svityčevo dopolnitvijo) (pie. *dh $u h_{2}$ mós $>$ pbsl. *'dúmas 'dim') in posledično nastanek prabaltoslovanskih bariton iz dela praindoevropskih oksiton;

(2) oblikovanje prabaltoslovanske naglasne valence morfemov na osnovi njihove praindoevropske naglašenosti oziroma nenaglašenosti (pie. * $h_{2}$ ul h $h_{2}$ neh,

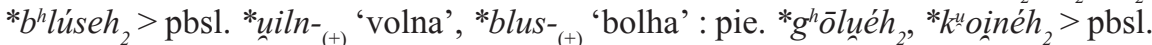
*galu- $_{(-)}$'glava', *kain- ${ }_{(-)}$'cena');

(3) nastanek prabaltoslovanskih tonemskih nasprotij akut : cirkumfleks/kračina na osnovi praindoevropskih kolikostnih nasprotij dolžina : kračina (prvi de Saussurjev zakon ali zakon stóti) (pie. *plh nós, *létipeh, : *ul̆ $k^{u} O s>$ pbsl. *pílnas 'poln', *léipấ 'lipa' : *uĩlkas 'volk');

(4) prabaltoslovanska metatonija tipa recesivni akut $>$ drugotno dominantni cirkumfleks v položaju pred naglasno dominantnim morfemom (pbsl. *gér téi $_{(-)}$:

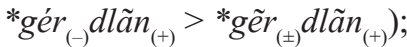

(5) nastanek prabaltoslovanskega mobilnega naglasnega tipa iz indoevropskega oksitoniranega ali mobilnega naglasnega tipa po vzoru indoevropskega amfikinetičnega naglasno-prevojnega tipa (pie. * $g^{h} \bar{o} l u e ́ h_{2},{ }^{*} k^{u}$ oinnéh $\rightarrow$ pbsl. *gál'úa *gáluããn (II/1) 'glava', *kãii'ná *kãinã̃n (II/2) 'cena');

(6) praslovanski naglasni umik po Hirtovem zakonu (Illič-Svityčeva dopolnitev za slovanščino) (pbsl. *grúż'téi, *gér'téi (II/1)> psl. *grÿzti, *žérti (c/a); pbsl.

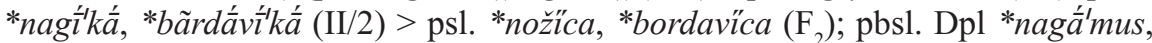
Lpl *nagáa'su, Ipl *nagấ'mí́s > psl. Dpl *nogämъ, Lpl *nogäxъ, Ipl *nogämi) in po-

${ }^{38}$ Baltščina in slovanščina se v vseh primerih naglasno ne ujemata, kar bi lahko kazalo na različni praindoevropski naglasni izhodišči vzporednice na segmentni ravni: lit. rankà,

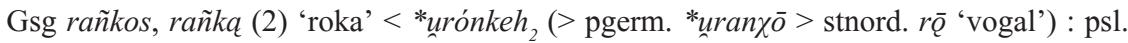
*rokà *rọko (c) 'roka' (> knj. sln. (róka) rokộ, nar. sln. rọ́ka rokộ, nštok. rúka rûku, čak. rūkä rûku, rus. рукá ру́кy, с̌eš. ruka ruku)< *uronkéh ${ }_{2}$ (> pgerm. *urangō > stnord. rong 'rebro') (Illič-Svityč 1963: 23-24, 101). 
$-\quad$ sledično nastanek praslovanskih naglasnih tipov c/a in $\mathrm{F}_{2}$ znotraj baltoslovanskega [स] naglasnega tipa II/1;

(7) praslovanski naglasni pomik po Dybojevem zakonu (pbsl. *b'lusáa * $b^{\prime} l u s \tilde{\tilde{a}} n$

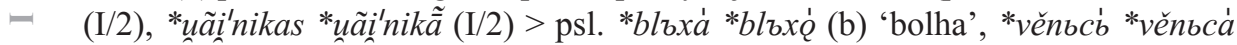
(B) 'venec') in posledično nastanek praslovanskega naglasnih tipov b, B, D, E, F , $\mathrm{G}$ iz prabaltoslovanskega naglasnega tipa $\mathrm{I} / 2$;

(8) praslovanska nevtralizacija tonemskih nasprotij $v$ fonološko nenaglašenih oblikah (Meilletov zakon) in posledično sovpad prabaltoslovanskih naglasnih tipov II/1 in II/2 v praslovanski naglasni tip c/C v večini primerov (Asg pbsl. *gáluã (II/1), *kãinnã̃n (II/2) > psl. *gôluo (c) 'glava', *cêno (c) 'cena');

(9) poznopraslovanski naglasni umik s polglasnika v šibkem položaju in posledično nastanek poznopraslovanskega novega akuta (psl. *morišb, *nesešb́, *tręsešb, *gryzě̌s > *moríšb, *nesèšb, *tręsèšb, *gryzèšb);

(10) poznopraslovanski naglasni umik z nestaroakutiranega srednjega zloga znotraj praslovanskega naglasnega tipa $b$ in posledično nastanek poznopraslovanskega novega akuta (psl. *možéšb *možète; *blodišb *blodite, *nosišb *nosite > *mòžě́b *mòžete; *blọdišb *blódite, *nòsišs *nòsite).

\section{Literatura}

Bezlaj 1995 = France Bezlaj, Etimološki slovar slovenskega jezika III, Ljubljana, 1995.

Bezzenberger 1877 = Adalbert Bezzenberger, Beiträge zur Geschichte der litauischen Sprache auf Grund litauischer Texte des XVI. und XVII. Jahrhunderts, Göttingen, 1877.

Dolobko 1927 = Милий Долобко, Но́чь - ноче́сь, о́сень - осене́сь, зима́ зиму́сь, ле́то - ле́тось, Slavia (Praha) 5 (1927), 678-717.

Dybo 1958 = Владимир Антонович Дыбо, О древнейшей метатонии в славянском глаголе, Вопросы языкознания (Москва), 1958, № 6, 55-62.

Dybo 1971 = Владимир Антонович Дыбо, Закон Васильева-Долобко и акцентуация форм глагола в древнерусском и среднеболгарском, Вопросы языкознания (Москва) 1971, № 2.

Dybo 1971a = Владимир Антонович Дыбо, О фразовых модификациях ударения в праславянском, Советское славяноведение (Москва) 1971, № 6.

Dybo 1981 = Владимир Антонович Дыбо, Славянская акцентология, Москва, 1981.

Dybo 2000 = Владимир Антонович Дыбо, Морфологизованные парадигматические акцентные системы, Москва, 2000.

Dybo - Zamjatina - Nikolajev 1990 = Владимир Антонович Дыбо - Галина Игоревна Замятина - Сергей Львович Николаев, Основы славянской акцентологии, Москва, 1990.

Dybo - Zamjatina - Nikolajev 1993 = Владимир Антонович Дыбо - Галина Игоревна Замятина - Сергей Львович Николаев, Основы славянской акцентологии: словарь, Москва, 1993. 
Forssman 2001 = Berthold Forssman, Lettische Grammatik, Dettelbach: Verlag J. H. Röll, 2001 (Münchener Studien zur Sprachwissenschaft 20).

Fortunatov $1880=$ Filip Fëdorovič Fortunatov, Zur vergleichenden Betonungslehre der lituslavischen Sprachen, Archiv für slavische Philologie (Berlin) 4 (1880), 575-589.

Hanssen 1885 = Friedrich Hanssen, Der griechische circumflex stammt aus der ursprache, Zeischrift für vergleichende Sprachforschung 27 (1885), 612-617.

Hirt 1893 = Hermann Hirt, Zu den slavischen Auslautsgesetzen, Indogermanische Forschungen (Strassburg) 2 (1893), 337-364.

Hirt 1895 = Hermann Hirt, Der indogermanische Akzent: ein Handbuch, Strassburg, 1895.

Hraste - Šimunović 1979 = Mate Hraste - Petar Šimunović, Čakavisch-deutsches Wörterbuch, unter Mitarbeit und Redaktion von Reinhold Olesch, Köln Wien: Böhlau Verlag, 1979.

Illič-Svityč 1963 = Владислав Маркович Иллич-Свитыч, Именная акиентуащия в балтийском и славянском: судьба акцентуачионных парадигм, Москва, 1963.

Ivšić 1911 = Stjepan Ivšić, Prilog za slavenski akcenat, Rad Jugoslavenske akademije znanosti i umjetnosti (Zagreb) 187 (1911), 133-207.

Jakobson 1963 = Роман Осипович Якобсон, Опыт фонологического подхода к историческим вопросам славянской акцентологии, American Contributions to the Fifth International Congress of Slavists: Sofia, 1963, The Hague, $1963,1-26$.

Kortlandt 1974 = Frederik Kortlandt, Old Prussian accentuation, Zeitschrift für vergleichende Sprachforschung 88 (1974), 299-309.

Lehfeldt 2009 = Werner Lehfeldt, Einführung in die morphologische Konzeption der slavischen Akzentologie, München, ${ }^{3} 2009$ ( $\left.{ }^{1} 1993,{ }^{2} 2001\right)$.

Leskien 1881 = August Leskien, Die Quantitätsverhältnisse im Auslaut des Litauischen, Archiv für slavische Philologie, Heidelberg 5 (1881), 188-190.

Lietuvių kalbos institutas 1997 = Lietuvių kalbos institutas, Dabartinès lietuviu kalbos gramatika, Vilnius, ${ }^{3} 1997$.

Lietuvių kalbos institutas $2000=$ Lietuvių kalbos institutas, Dabartinès lietuviu kalbos žodynas, Vilnius, ${ }^{4} 2000$.

Lončarić 1996 = Mijo Lončarić, Kajkavsko narječje, Zagreb, 1996.

Mathiassen 1996 = Terje Mathiassen, A short grammar of Lithuanian, Columbus, 1996.

Meier-Brügger 2010 = Michael Meier-Brügger, Zu den Flexionsparadigmen und ihren Ablautklassen, Indogermanische Sprachwissenschaft, Berlin - New York, ${ }^{3} 2010\left({ }^{1} 2000,{ }^{2} 2002\right)$.

Meillet 1902 = Antoine Meillet, О нъкоторыхъ аномаліяхъ ударенія въ славянскихъ яыкахъ, Русскій филологическій въстникъ (Warszawa) 48 (1902), № 3-4, 193-200.

Piesarskas - Svecevičius 2002 = Bronius Piesarskas - Bronius Svecevičius, Naujasis lietuviu-anglu kalbu žodynas, Vilnius, 2002. 
- Pleteršnik = Maks Pleteršnik, Slovensko-nemški slovar: transliterirana izdaja, Ljubljana, $2006\left({ }^{1} 1894 / 95\right)$ (elektronska različica).

de Saussure 1894 = Ferdinande de Saussure, À propos de l'accentuation lituanienne, Mémoires de la Société de Linguistique de Paris (Paris) 8 (1894), 425-446.

de Saussure 1896 = Ferdinande de Saussure, Accentuation lituanienne, Anzeiger für indogermanische Sprach- und Altertumskunde: Beiblatt zu den Indogermanischen Forschungen (Straßburg) 6 (1896), 157-166.

Snoj 2003 = Marko Snoj, Slovenski etimološki slovar, Ljubljana, 2003 ( $\left.{ }^{1} 1997\right)$.

Snoj 2009 = Marko Snoj, Etimološki slovar slovenskih zemljepisnih imen, Ljubljana, 2009.

$\mathrm{SP}=$ Slovenski pravopis, Ljubljana, 2001 (elektronska različica).

SSKJ = Slovar slovenskega knjižnega jezika I-V, Ljubljana, 1970-1991 (elektronska različica).

Stang 1957 = Christian S. Stang, Slavonic Accentuation, Oslo, 1957.

Stanonik 1977 = Marija Stanonik, Govor Žirovske kotline in njenega obrobja, Slavistična revija (Ljubljana) 25 (1977), 293-309.

Steenwijk 1992 = Han Steenwijk, The Slovene dialect of Resia: San Giorgio, Amsterdam - Atlanta (GA), 1992.

Streitberg 1894 = Wilhelm Streitberg, Die indogermanische Sektion auf der Wiener Philologenversammlung, 23.-27. Mai 1893, Anzeiger für indogermanische Sprach- und Altertumskunde: Beiblatt zu den Indogermanischen Forschungen (Straßburg) 3 (1894), № 6, 162-168.

Stundžia 1995 = Bonifacas Stundžia, Lietuvių bendrinès kalbos kirčiavimo sistema, Vilnius, 1995.

Šahmatov 1901 = Александр А. Шахматов, Die serbokroatische Betonung südwestlicher Mundarten von Milan Rešetar, Wien, 1900, Извъстія отдъленія русскаго языка и словесности Императорской акедеміи наукъ (Санктпетербургъ) 6 (1901 (1903)), 339-353.

Šahmatov 1915 = Александр А. Шахматов, Очеркъ древнъйшаго періода исторіи русскаго языка, Петроградъ, 1915.

Šekli, Matej: Ledinska imena v kraju Livek in njegovi okolici: doktorsko delo, Ljubljana, 2006 (razmnoženo).

Vasiljev 1905 = Леонид Лазаревич Васильев, Къ исторіи звука ь въ московскомъ говоръ в XIV-XVII въкахъ, Извъстія отдъленія русскаго языка и словесности Императорской акедеміи наукъ (Санктпетербургъ) 10 (1905), № 2,177-227.

Vasiljev 1905a = Леонид Лазаревич Васильев, Замътка объ акцентовкъ несклоняемаго причастія на -ль, Журналь Министерства народнаго просвъщенія (С.-Петербургъ) 1905, авг., 464-469.

Vasiljev 1929 = Леонид Лазаревич Васильев, О значении каморы в некоторых древнерусских памятниках XVI-XVII веков: к вопросу о произношении звука о в великорусском неречии, Сборник по русскому языку и словесности (Ленинград) I (1929), № 2.

Zaliznjak 1985 = Андрей Анатольевич Зализняк, Om праславянской акиентуаичии к русской, Москва, 1985. 


\section{Prehistory of the Proto-Slavic accent system according to the Moscow Accen- tological School}

\section{Summary}

According to the Moscow Accentological School, the relative chronology of accent-related phenomena from Proto-Indo-European through Proto-Balto-Slavic to Proto-Slavic appears to be as follows:

(1) Proto-Balto-Slavic accent retraction by Hirt's Law (in Illič-Svityč's modification) (PIE. *dh $d^{h} h_{2}$ mós $>$ PBS. *'dúmas 'smoke'), which is, consequently, responsible for the transition of the affected Proto-Indo-European oxytones to ProtoBalto-Slavic baritones;

(2) The emergence of Proto-Balto-Slavic accentual valence in morphemes, constituted on the basis of Proto-Indo-European stress (PIE. * $h_{2} u l_{0} h_{2} n e h_{2}, * b^{h} l u s e h_{2}$

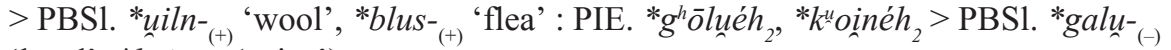
'head', *kain- ${ }_{(-)}$'price');

(3) The manifestation of Proto-Indo-European quantitative opposition long vs. short as Proto-Balto-Slavic tonal opposition acute vs. circumflex or short (de Saussure's First Law or the "stóti" Law) (PIE. *plh nós, *léipeh, : *uĺlk $k^{u} o s>$ PBSl. *pílnas 'full', *léipấ 'lime' : *uîlkas 'wolf');

(4) Proto-Balto-Slavic metatony of the type recessive acute $>$ circumflex of secondary dominance before an accentually dominant morpheme (PBSl. *gér ${ }_{(-)}$téi $\left.i_{(-)}: *^{g} e ́ r_{(-)} d l \tilde{a} n_{(+)}>*_{g e \tilde{r}}(d) \tilde{d}_{(+)}\right)$;

(5) The development of the mobile Proto-Balto-Slavic accentual paradigm, based on Proto-Indo-European oxytones or mobile accentual paradigms remodeled on the amphikinetic accent-ablaut type reconstructed for Proto-Indo-European

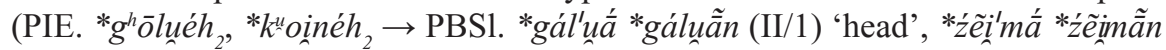
(II/2) 'winter');

(6) Proto-Slavic accent retraction by Hirt's Law (modification for Slavic by Illič-Svityč) (PBSl. *grúzźtéi, *gér'téi (II/1) > PSl. *grÿzti 'to bite', *žěrti (c/a) 'to devour'; PBS1. *nagì'k kâa, *bãrdấvî́l'kấ (II/2) > PS1. *nožíca 'small foot', *bordavïca

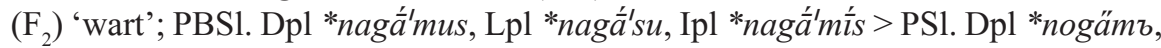
Lpl *nogäxz, Ipl *nogämi 'legs') and, consequently, the development of ProtoSlavic accentual paradigms $\mathrm{c} / \mathrm{a}$ and $\mathrm{F}_{2}$ from Proto-Balto-Slavic accentual paradigm II/1;

(7) Proto-Slavic accent shift by Dybo's Law (PBSl. *b'lusấ *b'lusã̃n (I/2), *uãi'nikas *uãi'nikō (I/2) > PSl. *blbxá *blbxó (b) 'flea', *věnbcb́ *věnbcà (B) 'wreath') and, consequently, the development of Proto-Slavic accentual paradigms b, B, D, E, F and G from Proto-Balto-Slavic accentual paradigm I/2;

(8) Proto-Slavic tonal neutralization in phonologically unstressed forms (Meillet's Law), which in the majority of cases led to the merger of Proto-BaltoSlavic accentual paradigms II/1 and II/2, now constituting Proto-Slavic accentual paradigm c (Asg PBSl. *gáluã̃̄n (II/1), *kãainã̃n (II/2) > PSl. *gôlue (c) 'head', *cêno $(\mathrm{c})$ 'price'); 
(9) Late-Proto-Slavic accent retraction from the reduced vowels jer or jor in so-called weak position, leading to the appearance of the Late-Proto-Slavic neoN acute toneme (PSl. *morišb, *nesešb, *tręsešb, *gryzešb > *moríšb 'you murder', - * * *nesèšb 'you carry', *tręsèšb 'you agitate', *gryzèšb 'you bite');

(10) Late-Proto-Slavic accent retraction from vowels with non-acute intonation in medial syllables (affecting accentual paradigm b) and, consequently, the emergence of the Late-Proto-Slavic neo-acute toneme (PS1. *možéšb *možéte;

- *blodišb *blodite, *nosišb *nosite > *mòžešb *mòzete 'you can'; *blódišb *blódite 'you roam', *nòsišb *nòsite 'you carry'). 